\title{
Review
}

\section{Metabolic Therapy of Heart Failure: Is There a Future for B Vitamins?}

\author{
Jérôme Piquereau *D, Solène E. Boitard, Renée Ventura-Clapier and Mathias Mericskay *(D) \\ UMR-S 1180, Inserm Unit of Signaling and Cardiovascular Pathophysiology, Faculty of Pharmacy, \\ Université Paris-Saclay, 92296 Chatenay-Malabry, France; Solene.boitard@inserm.fr (S.E.B.); \\ renee.ventura@universite-paris-saclay.fr (R.V.-C.) \\ * Correspondence: jerome.piquereau@universite-paris-saclay.fr (J.P.); mathias.mericskay@inserm.fr (M.M.); \\ Tel.: +33-146-835-325 (M.M.)
}

Citation: Piquereau, J.; Boitard, S.E.; Ventura-Clapier, R.; Mericskay, M. Metabolic Therapy of Heart Failure: Is There a Future for B Vitamins? Int. J. Mol. Sci. 2022, 23, 30. https:// doi.org/10.3390/ijms23010030

Academic Editor: Christian Jung

Received: 3 November 2021

Accepted: 20 December 2021

Published: 21 December 2021

Publisher's Note: MDPI stays neutral with regard to jurisdictional claims in published maps and institutional affiliations.

Copyright: (C) 2021 by the authors. Licensee MDPI, Basel, Switzerland. This article is an open access article distributed under the terms and conditions of the Creative Commons Attribution (CC BY) license (https:// creativecommons.org/licenses/by/ $4.0 /)$.

\begin{abstract}
Heart failure (HF) is a plague of the aging population in industrialized countries that continues to cause many deaths despite intensive research into more effective treatments. Although the therapeutic arsenal to face heart failure has been expanding, the relatively short life expectancy of HF patients is pushing towards novel therapeutic strategies. Heart failure is associated with drastic metabolic disorders, including severe myocardial mitochondrial dysfunction and systemic nutrient deprivation secondary to severe cardiac dysfunction. To date, no effective therapy has been developed to restore the cardiac energy metabolism of the failing myocardium, mainly due to the metabolic complexity and intertwining of the involved processes. Recent years have witnessed a growing scientific interest in natural molecules that play a pivotal role in energy metabolism with promising therapeutic effects against heart failure. Among these molecules, B vitamins are a class of water soluble vitamins that are directly involved in energy metabolism and are of particular interest since they are intimately linked to energy metabolism and HF patients are often B vitamin deficient. This review aims at assessing the value of B vitamin supplementation in the treatment of heart failure.
\end{abstract}

Keywords: heart failure; energy metabolism; mitochondria; B vitamins; thiamin; riboflavin; nicotinamide; pyridoxine; folate; cobalamin; metabolic therapy

\section{Introduction}

Heart failure (HF), as the outcome of many cardiovascular diseases, is one of the major causes of death in industrialized countries and a substantial economic burden worldwide. According to recent estimations, 1 to $2 \%$ of the global adult population could be affected by this syndrome, with a prevalence of approximately 65 million patients worldwide [1]. This figure is expected to increase as the population ages, urging the scientific community to expand their therapeutic arsenal to improve the survival rate of HF patients. Although intensive research in the last decades has improved our understanding of HF pathophysiology and the means to tackle it, the 5-year survival rate of 55 to $60 \%$ remains unsatisfying [2]. Standard HF therapies target the dysregulation of the neurohormonal system or reduce the cardiac workload. These therapies, however, neglect the profound alterations of energy metabolism encountered in HF due to the lack of efficient tools for the metabolic treatment of this syndrome. Current knowledge suggests that new therapies aiming at restoring the energy balance in the heart should be used on top of current therapies to better treat HF patients and improve quality of life and possibly survival.

The heart is one of the main energy consumers of the body owing to its incessant and rhythmic blood pumping activity throughout the circulatory system. Cardiac contractile properties rely on molecular mechanisms involving ATPases (sarcoplasmic/endoplasmic reticulum Ca2+ ATPase and myosin ATPase especially) that require suitable energy production since cardiomyocytes stocks of high-energy phosphate molecules; i.e., adenosine triphosphate (ATP) and phosphocreatine (PCr), can only ensure cardiac contraction for a 
few seconds only. This limitation imposes the requirement of the constant production of energy molecules to adapt to the fluctuating cardiac demand. The heart is thus endowed with impressive ATP production capacities depending on tightly regulated metabolic processes, the alterations of which have extensively been described in HF settings since the 1980s [3]. It is now clear that the failing heart can be considered as an engine unable to properly oxidize fuel and sustain its own energy demand with 25-35\% lower ATP content and $40-50 \%$ lower PCr content than a healthy heart [4-6]. This incapacity is due to profound perturbations in the regulations and the efficiency of many reactions/processes involved in energy molecule production [7]. Despite intensive work in this field, identifying novel therapeutic strategies remain challenging. Cardiac energy metabolism exhibits a high complexity involving many interlaced signaling pathways. Any metabolic therapy aiming at restoring the energetic disorders of the failing heart necessitates the development of global strategies that would impact all the actors of the energy machinery of the cardiomyocyte. Numerous recent strategies using synthetic chemical compounds to target specific aspects of energy metabolism have been proposed and tested with mitigated success so far [8,9], prompting the search for new compelling alternatives.

Natural compounds, including vitamins, are increasingly gaining scientific attention due to their significant involvement in numerous elementary reactions of cellular homeostasis [10]. Vitamin supplementations have already been part of treatments of specific diseases for many years [11,12] and have also been tested in the frame of HF with variable degrees of success [13]. However, conflicting results from a series of small clinical studies [14-20] only showed that more research is needed to better define which type of vitamin supplementation protocol should be implemented and which HF etiologies and stages of the syndrome should selectively be targeted by these potential treatments. To face the profound metabolic disorders described in HF, the big family of $\mathrm{B}$ vitamins are emerging as promising supplements to manage HF for two main reasons; first, B vitamins are highly involved in numerous elementary processes of cardiac energy metabolism [21] and second, B vitamins are deficient in HF patients due to the use of diuretics, malnutrition, and advanced age [22,23]. Vitamins are precursors of essential coenzymes playing a major role in energy metabolism. In this review, we describe the main features of cardiac energy metabolism in the healthy heart and its abnormalities in HF with emphasis on the role of $B$ vitamins. We then review the use of $B$ vitamins in the preclinical and clinical context of $\mathrm{HF}$ while assessing the value of B vitamin supplementation in the treatment of this debilitating syndrome.

\section{The Heart: An Oxidative Tissue}

The heart never stops beating from early in utero life and throughout the lifetime. Cardiac function demands a large amount of energy, cycling approximately $6 \mathrm{~kg}$ of ATP each day [24]. The healthy mature heart obtains energy by metabolizing a large variety of energy substrates depending on substrate availability and/or energy demand. For that reason, the heart is qualified as a metabolic omnivore. Under normal conditions, energy molecules are mainly (60\% to $90 \%$ ) generated from the metabolism of fatty acids (FA), while the remaining molecules are produced from carbohydrates through pyruvate oxidation $[7,9,25]$. Under specific conditions, such as long fasting, the heart resorts to alternative energy producing substrates, including lactate, ketone bodies, and amino acids, especially branched-chain amino acids (BCAA). Cardiomyocytes are thus equipped with a whole range of substrate-specific membrane transporters, the expression of which is modulated according to the cardiac environment [26,27]. As the heart exhibits a low storage ability, they allow the constant entry of these substrates to supply the energy machinery. The production of ATP within the cardiomyocyte strongly relies on the mitochondrial oxidative function, which provides $90 \%$ to $95 \%$ of energy molecules from the oxidation of the aforementioned substrates $[7,28]$. The remaining $5 \%$ to $10 \%$ are produced by the anaerobic glycolysis pathway, degrading glucose to pyruvate. However, pyruvate can enter mitochondria for further catabolism processes, in which case the full process, cytosolic 
glycolysis and pyruvate oxidation, is called glucose oxidation. The flux of a given substrate to oxidative pathways is largely dependent on the expression and the activity of ratelimiting enzymes that are respectively modulated by transcriptional and post-translational processes, which are under the control of many intertwined signaling pathways including pathways regulated by vitamins, as will be detailed later. In the end, the orientation of the cardiac metabolism is the result of intricate machinery in which the availability of the substrates itself plays a key role. For instance, the oxidation of a specific substrate can favor the mechanisms responsible for its degradation while repressing the utilization of any other potential energy sources. This phenomenon involves feedback mechanisms known as the Randle cycle [29], in which FA oxidation inhibits glucose utilization and vice versa, underlying the flexibility of cellular metabolism that is able to adapt to the changes of the cell environment.

Regardless of the type of recruited substrates, their oxidation consists of producing reducing agents (NADH and $\mathrm{FADH}_{2}$ ) that will then act as electron donors to the mitochondrial electron transfer chain (ETC). The energy resulting from electron flow within this chain is coupled to proton translocation from the matrix to the intermembrane space of the mitochondria. Thus, the energy produced from substrate oxidation is transformed into a chemical and electrical gradient, the proton motive force, which in turn is used by the $F_{O} / F_{1}$ ATP synthase of the mitochondrial inner membrane to rephosphorylate ADP [30]. ATP production is dependent on the return of the protons accumulated in the intermembrane space to the matrix through the $\mathrm{F}_{\mathrm{O}}$ portion of the ATP synthase, inducing the rotation of the $\gamma$ subunit of the $F_{1}$ portion [31]. As a consequence, the proton gradient generated by the ETC is consumed as the ATP is produced and has to be constantly re-established using reduced coenzymes, $\mathrm{NADH}$, and $\mathrm{FADH}_{2}$ (Figure 1). This requires not only efficient catabolic machinery able to generate a large number of reduced coenzymes but also a suitable oxygen supply to receive the electrons travelling through ETC. In the mitochondrial matrix, $\mathrm{NADH}$ and $\mathrm{FADH}_{2}$ are generated by the tricarboxylic acid (TCA) cycle, also known as the Krebs cycle, and fatty acid $\beta$-oxidation reactions. TCA corresponds to a series of chemical reactions involving specific enzymes including several dehydrogenases, this results in the generation of three molecules of NADH and one molecule of $\mathrm{FADH}_{2}$ per cycle (Figure 1). The TCA cycle is initiated by citrate synthase (CS) which catalyses the condensation of oxaloacetate, produced after the completion of a round of TCA, and acetyl-CoA, the common end product of all substrate oxidation pathways, including the pyruvate dehydrogenase complex, fatty acid $\beta$-oxidation (FAO), the degradation of ketone bodies, and BCAA. As catabolic pathways of the above-mentioned substrates all converge on TCA [7], this process plays a central role in the production of energy molecules in cardiomyocytes as well as in the responsiveness of the energy molecule production machinery, which has to adapt quickly and continuously to heart energy demand. Indeed, while ATP production is paced by its own consumption as ADP stimulates ATP synthase activity [32,33], the regeneration of the reduced coenzymes that support ADP rephosphorylation is accelerated by activation of TCA dehydrogenases. These enzymes, as well as the ATP synthase, are sensitive to the intramitochondrial calcium concentration that increases when cardiac function is challenged since the rate and amplitude of cytosolic calcium transient increases under sympathetic stimulation [34-36]. Thus, the perfect coordination between the consumption and production of energy molecules relies on the complementary roles of ADP and calcium which act as signalling molecules to meet energy demand. In addition, the stimulation of TCA reactions by calcium also allows the higher production of compounds leading to NADPH production which is required for reactive oxygen species (ROS) detoxifying systems to avoid oxidative damage that could be really harmful in such an oxidative tissue. 


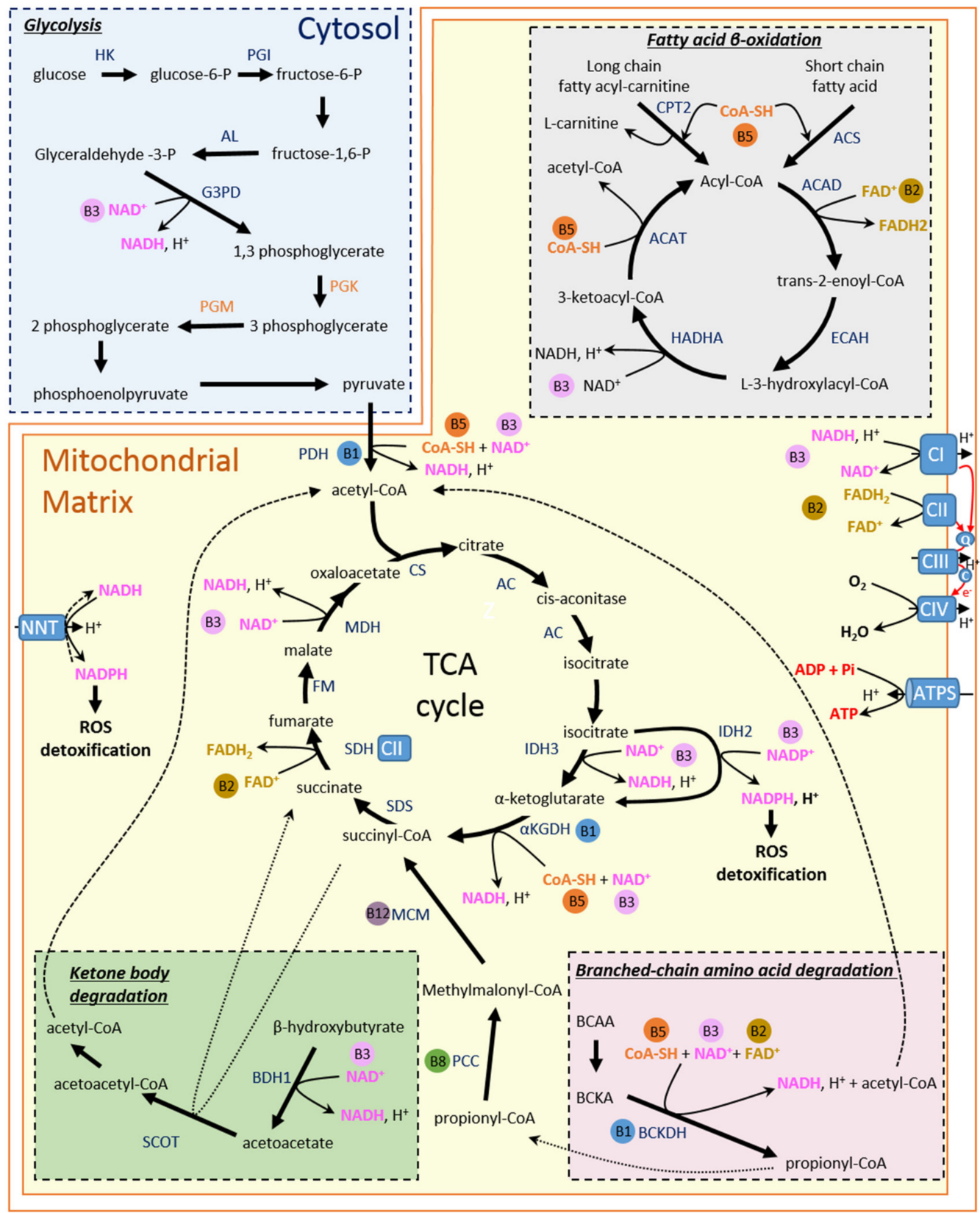

Figure 1. Role of $B$ vitamins in energy metabolism processes in cardiomyocytes. AC, aconitase ACAD, acyl-CoA dehydrogenase; ACAT, acyl-CoA thiolase; ACS, acyl CoA synthetase; AL, aldolase; BCAA, branched-chain amino acid; BCAT, branched-chain amino acid transaminase; BCKA, branched-chain keto acids; $\mathrm{BCKDH}$, branched-chain keto acid dehydrogenase; $\mathrm{BDH} 1$, beta-hydroxybutyrate dehydrogenase; $\mathrm{CPT} 2$, carnitine O-palmitoyltransferase 2; $\mathrm{CoA}-\mathrm{SH}$, Coenzyme A; CS, citrate synthase; $\mathrm{ECAH}$, Enoyl-CoA hydratase; EL, enolase; $\mathrm{FAD}^{=}$, flavin adenine nucleotide; $\mathrm{FADH}_{2}$, reduced form of $\mathrm{FAD}^{+}$; G3PD, glyceraldehyde-3-phosphate dehydrogenase; FM, fumarase, HADHA, L-3-hydroxyacyl-CoA dehydrogenase; $\mathrm{HK}$, hexokinase; IDH, isocitrate dehydrogenase; $\alpha \mathrm{KGDH}$, alpha-ketoglutarate dehydrogenase; $\mathrm{MCM}$, methylmalonyl-CoA mutase; $\mathrm{MDH}$, malate dehydrogenase, $\mathrm{NAD}^{+}$, nicotinamide adenine dinucleotide; $\mathrm{NADH}$, reduced form of $\mathrm{NAD}^{+}$; PCC, propionyl-CoA carboxylase; $\mathrm{PDH}$, pyruvate dehydrogenase; PGI, phosphoglucose isomerase; PGK, phosphoglycerate kinase; PGM, phosphoglycerate mutase; PK, pyruvate kinase; SCOT, succinyl-CoA:3 oxoacid-CoA transferase SDH, succinate dehydrogenase; SDS, succinyl-CoA synthase; TCA, tricarboxylic acid.

This brief description of cardiac energy metabolism clearly highlights the complexity of the whole process and the multitude of actors, as well as the central role of the mitochon- 
dria. It implies fine-tuning to ensure the presence of adequate enzymes and a functional mitochondrial pool over time.

\section{Energy Metabolism in Healthy Heart}

\subsection{Fatty Acid}

FAs are the preferential substrates of the heart to produce energy molecules. Although this source of fuel requires a high number of $\mathrm{O}_{2}$ molecules per ATP produced; for instance, the complete oxidation of palmitate generates 105 molecules of ATP and consumes 46 oxygen atoms yielding a $\mathrm{P} / \mathrm{O}$ ratio of 2.33, allows the generation of large amounts of ATP in conditions where oxygen and mitochondrial capacities are not limiting. This can become an issue in the failing heart, as will be detailed later in this review.

The heart is supplied with blood circulating FAs that must pass several biomembranes to access cardiomyocyte cytosol. Due to their lipophilic property, FAs have long been thought to cross those membranes by passive diffusion. The transfer of these lipids to an intracellular medium is facilitated by membrane-associated fatty acid-binding proteins, usually called fatty acid transporters, such as fatty acid translocase (FAT/CD36) and fatty acid transport protein (FATP) [37]. At the outer mitochondrial membrane, long-chain FAs are transformed into fatty acyl-CoA by long-chain fatty acyl-CoA synthetase and are then transported into the mitochondrial matrix through the carnitine palmitoyltransferase (CPT) system [38]. Short-chain and medium-chain FAs can permeate the mitochondrial membrane in their non-esterified form and are activated to their acyl-CoA derivatives in the matrix by specific mitochondrial acyl-CoA synthetases. There, acyl-CoAs enter the $\beta$-oxidation reaction series, producing $\mathrm{NADH}, \mathrm{FADH}_{2}$, and acetyl-CoA that feeds the TCA cycle for further reducing agent production (Figure 1). The regulation of FA oxidation is quite intricate and occurs at many steps of this catabolic process. While one of the major points of this regulation is the control of FA entry into mitochondria by malonyl-CoA-induced CPT inhibition, the availability and the redox state of $\mathrm{FAD} / \mathrm{FADH}_{2}$ and $\mathrm{NAD} / \mathrm{NADH}$ can also play key roles in FA oxidation as they are required for the activity of acyl-CoA transferase and 3-hydroxyacyl-CoA dehydrogenase, respectively [39], two enzymes of the $\beta$-oxidation.

\subsection{Carbohydrates}

Unlike FAs, glucose is the most efficient energy substrate from an oxygen utilization point of view, with a P/O ratio of 2.58 (31 ATP produced/12 oxygen atoms consumed). Glucose enters the cardiomyocyte using specific glucose transporters GLUT1 and GLUT4. In the cell, glucose is transformed by hexokinase into glucose-6-phosphate, which initiates diverse series of reactions, including glycolysis (Figure 1), glycogen synthesis, or the pentose phosphate pathway. The production of ATP from glucose starts in the cytosol by metabolizing glucose to pyruvate, which generates 2 ATP molecules. Pyruvate is then either converted to lactate or taken to mitochondria by the mitochondrial pyruvate carrier. In the mitochondrial matrix, pyruvate dehydrogenase (PDH) generates acetyl-CoA using pyruvate, which initiates the TCA cycle, thereby producing reducing agents from carbohydrates (Figure 1). The entry of pyruvate into the TCA cycle is dependent on PDH activity which is accurately regulated by its phosphorylation state; this enzyme is actually activated by PDH phosphatase and inhibited by PDH kinase, which are important players in carbohydrate oxidation regulation [40].

\subsection{Ketone Bodies}

The ketone body (KB) family is an alternative form of energy that is produced by the liver. In normal conditions, the hepatocytes only ensure a moderate production of KBs, which is largely increased when the organism is facing metabolic stress such as a decrease in circulating carbohydrates or/and an increase in circulating FAs. Ketogenesis consists of the production of specific water-soluble lipid molecules called ketone bodies, among which acetone, acetoacetate, and $\beta$-hydroxybutyrate are the main species. 
The heart preferentially oxidizes $\beta$-hydroxybutyrate, the uptake of which is facilitated by monocarboxylate transporter 1 [41]. In cardiomyocytes, $\beta$-hydroxybutyrate enters into the mitochondria where it is converted into acetoacetate by $\beta$-hydroxybutyrate dehydrogenase; then it is used by CoA transferase succinyl-CoA:3 oxoacid-CoA transferase to produce acetoacetyl-CoA (Figure 1). This latter then undergoes a thiolysis reaction to produce acetyl-CoA, which enters the TCA cycle for further reducing agent production [42]. Although the heart is well-equipped to use $\mathrm{KBs}$, their contribution to energy molecule production is low in normal conditions as KB availability is poor. Yet, $\beta$-hydroxybutyrate has a $\mathrm{P} / \mathrm{O}$ ratio of 2.5 , making KBs easier to oxidize than FAs, notably in conditions of reduced mitochondrial oxidative capacities as in HF [7]. This is an important point to consider because $\mathrm{KB}$ utilization in the heart is obtained at the expense of FA and glucose oxidation since $\mathrm{KB}$ oxidation inhibits catabolic processes involving other kinds of substrates $[43,44]$.

\subsection{Branched-Chain Amino Acids}

Even though the major part of amino acid metabolism occurs in the liver, the subgroup of branched-chain amino acids (BCAA), including leucine, isoleucine, and valine, can be metabolized in non-hepatic tissue such as the heart, brain, or kidney. Briefly, BCAAs enters cardiomyocytes through transporters, which could be specific isoforms of L-type amino acid transporters and bidirectional transporters for L-glutamine and L-leucine/EAA similar to other cells $[45,46]$. There, they undergo transamination to their respective branchedchain $\alpha$-keto-acid (BCKA) by branched-chain amino-transferase located in mitochondria. $\mathrm{BCKA}$ are then used by branched-chain $\alpha$-keto-acid dehydrogenase (BCKDH) to produce acetyl-CoA and succinyl-CoA that can respectively enter the TCA cycle and replenish TCA intermediates (anaplerosis) (Figure 1) [47]. The main regulation mechanism involved in the use of BCAA as an energy source is based on the phosphorylation status of $\mathrm{BCKDH}$, which can be phosphorylated by BCKDH kinase and dephosphorylated by mitochondrialtargeted 2C-type ser/thr protein phosphatase ( $\mathrm{PP} 2 \mathrm{Cm})$, which controls BCAA-induced dephosphorylation of BCKDH [48]. PP2Cm has been shown to be highly expressed in the heart and is dynamically regulated by stress, thereby demonstrating the importance of BCAAs metabolism in this organ [49].

\section{Energy Metabolism and B Vitamins}

What are the roles of B vitamins in the regulation of energy metabolism? The family of B vitamins is a set of water-soluble vitamins which must be provided by daily diet in a suitable amount to ensure cellular homeostasis. They are involved in a plethora of crucial enzymatic reactions of diverse cellular processes, especially energy metabolism, in which they often act as cofactors or coenzymes for a number of enzymes participating in energy molecule production from the aforementioned substrates [21] (Figure 1). For instance, several B vitamins are directly involved in the TCA cycle, while others are required for NAD/FAD synthesis or for nucleotide synthesis and amino acid metabolism. These vitamins, therefore, play a central role in the energy machinery of the cell, a fortiori in the cardiomyocytes that consume a lot of energy, conferring credit to the hypothesis that vitamin supplementation could be part of the treatment of cardiac diseases associated with major disorders of energy metabolism.

\subsection{Vitamin $B 1$}

Vitamin B1 was one of the first vitamins described following the work of Casimir Funk, who sought to understand the causes of beriberi in the early 20th century. He coined the term vitamin from 'vita' (life) and 'amine' (nitrogen-containing compound), a nitrogenous substance that is important for life [50]. This vitamin, known as thiamine, is active in its thiamine diphosphate (TDP) form, which is a cofactor of cytosolic transketolase and three mitochondrial enzymes involved in energy production, namely mitochondrial pyruvate dehydrogenase (PDH) [51], $\alpha$-ketoglutarate dehydrogenase ( $\alpha-\mathrm{KGDH})$ [52], and branched-chain $\alpha$-keto-acid dehydrogenase (BCKDH) [53] (Figure 1). In the brain, a highly 
oxidative tissue such as the heart, it has been reported that only about $5 \%$ of thiamine is bound to cytosolic transketolase while the majority of the vitamin is concentrated in the mitochondria [54], thereby highlighting its major involvement in energy metabolism. Moreover, a recent study reinforced the idea that thiamine is a key element in mitochondrial energy production since thiamine and its derivatives could also allosterically regulate malate dehydrogenase [55], an enzyme involved in the malate aspartate shuttle which transfers reducing equivalents to regenerate $\mathrm{NADH}$ in the mitochondrial matrix using NADH produced by glycolysis in cytosol. While the mitochondrial thiamine partners described above clearly make vitamin B1 extremely important for energy homeostasis, its role as a cofactor of cytosolic transketolase is also very interesting since this enzyme catalyzes the first and last step of the pentose phosphate pathway allowing, on the one hand, NADPH production which is required to cellular antioxidant defenses (as a cofactor of glutathione reductase in particular) (Figure 2), and on the other hand, ribose generation for nucleotide synthesis.

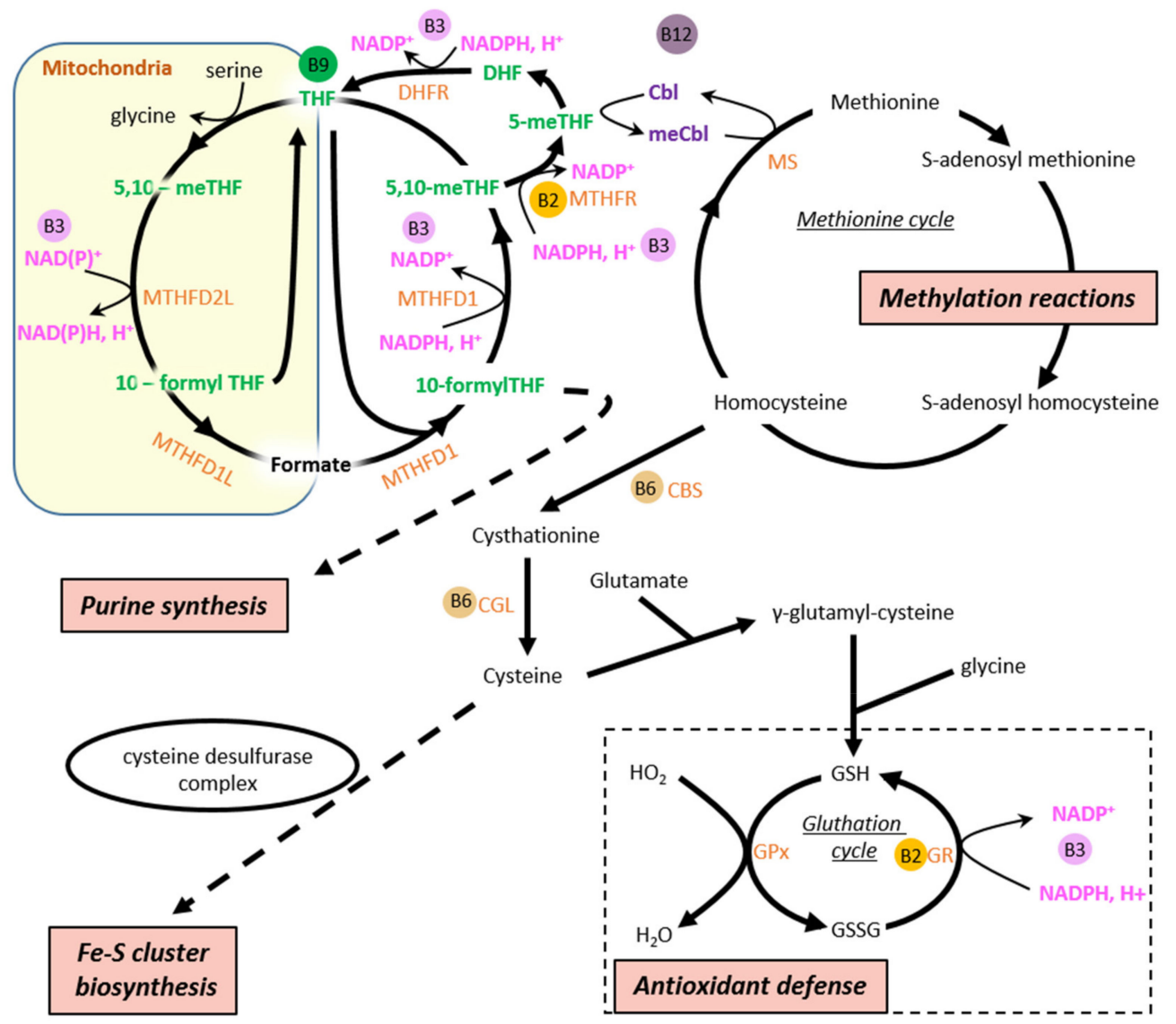

Figure 2. Involvement of $B$ vitamins in processes impacting energy metabolism. CBS, Cysthationine $\beta$ synthase; CGL, Cysthationine $\gamma$-liase; GPx, glutathione peroxidase; GR, glutathione reductase; GSH, glutathione; GSSG, glutathione disulfide; MS, methionine synthase; 5-MTHF, $5^{\prime}$ methymtetrafolate; 5,10-MTHF, 5,10-methylenetetrafolate; THF, tetrafolate; $\mathrm{NADP}^{+}$, nicotinamide adenine dinucleotide phosphate; NADPH reduced form of $\mathrm{NADP}^{+}$.

In mammals, vitamin B1 cannot be synthesized de novo and is generally found in raw food such as green vegetables, cereals, or egg yolk (a daily intake of $1 \mathrm{mg}$ is recommended). Its intestinal absorption requires a specific transporter (THTR-1), the expression of which is downregulated by alcohol; this explains the fact that alcoholism is one of the major causes of thiamine deficiency in industrialized countries [56,57]. Plasma thiamine is taken up by tissue via THTR1 and is transformed into TDP, the most part of which enters 
mitochondria via TDP/thiamin antiporter [58], where it binds to the above-mentioned mitochondrial enzymes.

\subsection{Vitamin B2}

Vitamin B2, namely riboflavin, is a major actor of energy metabolism as it is the precursor of flavin adenine dinucleotide (FAD) and flavin mononucleotide (FMN), which act as electron carriers. These two active forms of riboflavin, in particular FAD, are required for the operation of all flavoproteins, which catalyze redox and dehydrogenase reactions that are responsible for many steps in catabolism. Amongst the members of the flavoprotein family, a large part is located in the mitochondria, where they participate more or less directly in the production of energy molecules. This family includes a dozen of mitochondrial acyl-CoA dehydrogenases (ACAD), five of which are short, medium, long and very long-chain acyl-CoA dehydrogenases (SCAD, MCAD, VCAD, VLCAD1, and VLCAD2, also known as ACAD9). These are the enzymes involved in the first step of fatty acid $\beta$-oxidation $[59,60]$ (Figure 1). The chemical reactions performed by these ACADs lead to the production of $\mathrm{FADH}_{2}$, the electrons of which are given to ubiquinone (Coenzyme $\mathrm{Q}_{10}$ $\left.\left(\mathrm{CoQ}_{10}\right)\right)$ in the inner mitochondrial membrane through the electron transfer flavoprotein (ETF), thereby feeding the $\mathrm{CoQ}_{10}$ pool of mitochondrial ETC in the same way as complex I and II [60]. Riboflavin is also at the heart of the TCA cycle since it supports succinate dehydrogenase (SDH), also known as complex II of the ETC, which catalyzes the two-electron oxidation of succinate to fumarate with the concomitant reduction of $\mathrm{CoQ}_{10}$ (Figure 1). During this reaction, FAD bound to the Sdh1 subunit of $\mathrm{SDH}$ accepts electrons that are nearly instantaneously channeled through three iron-sulfur clusters of the Sdh2 subunit to ultimately reduce ubiquinone, consequently initiating the transfer of electrons within the ETC [61].

Beyond these essential roles in energy molecule production, riboflavin has a prominent place in the preservation of cellular functions and in particular mitochondrial functions. Indeed, FAD is bound to glutathione reductase (GR), close to the catalytic center [62], where it acts as a temporary acceptor of the electron within GR, which reduces glutathione disulfide (GSSG) to the sulfhydryl form glutathione (GSH) using NADPH (Figure 2). Riboflavin supply is thus required not only for energy metabolism but also for antioxidant defenses of the cell.

This vitamin is found in high quantities in eggs, lean meats, milk, green vegetables, and fatty fish, and the recommended daily intake of riboflavin is approximately $1 \mathrm{mg}$ [63] In food, riboflavin is found under its FAD and FMN forms which must be hydrolyzed before intestine absorption. This later occurs in the proximal small intestine via specific active riboflavin transporters (RFVTs) and is then released into the plasma to be distributed to the tissues [64].

\subsection{Vitamin B3}

Vitamin B3, the precursor of the NAD coenzyme, was discovered in the early 20th century when deciphering the cause of pellagra, characterized by darkly pigmented skin rash, dermatitis, diarrhea, and dementia $[65,66]$. Vitamin B3 is found under diverse dietary forms that comprise nicotinic acid (NA) (also known as niacin), nicotinamide (NAM), and nicotinamide riboside (NR) [67]. NAD can also be generated de novo from the essential amino acid tryptophan, essentially in the liver, but it is a less efficient precursor as $60 \mathrm{mg}$ of Trp is considered the equivalent of $1 \mathrm{mg}$ of niacin [67]. The nicotinamide mononucleotide (NMN), a phosphorylated intermediate in the synthesis of NAD can also be considered as a precursor since exogenous NMN administration raises NAD levels in various cell lines and tissues [68], and an NMN transporter (Slc12a8) has recently been identified in the murine small intestine [69]. However, the latter finding has been disputed based on technical consideration and the fact that in many cells, NMN-stimulated synthesis of NAD depends on the action of $5^{\prime}$-ectonucleotidase (also known as CD73) that converts it into NR [70]. 
NAD is a major coenzyme for fuel oxidation that is involved in diverse steps of anaerobic glycolysis, TCA cycle, $\beta$-oxidation, ketones oxidation as well as BCAA degradation (Figure 1). This leads to the donation of two electrons to the oxidized form $\mathrm{NAD}^{+}$producing NADH. In the mitochondria, NADH gives its electrons to mitochondrial complex I, thereby initiating the electron transfer within the ETC, allowing the translocation of the protons to intermembrane space. NAD is, therefore, an essential coenzyme that, together with FAD, constitute electrons carriers allowing the transformation of the energy substrates into usable energy under the form of ATP.

NAD is also the unique precursor of NADP, produced from NAD phosphorylation by NAD kinases in the cytosol (NADK1) and mitochondria (NADK2) [71]. NADP ${ }^{+}$is reduced to NADPH through different pathways such as the pentose phosphate pathway or the cytosolic and mitochondrial isocitrate dehydrogenases 1 and 2, respectively [72,73] (Figure 1, shown for IDH2 in the mitochondrial matrix). NADPH constitutes the final reducing power for the enzymatic systems detoxifying reactive oxygen species (ROS) (Figure 2). In the mitochondrial matrix, reducing equivalent from the NADH generated from the fuel oxidation process can also be directly transferred to $\mathrm{NADP}^{+}$by the nicotinamide nucleotide transhydrogenase (NNT) to generate NADPH, therefore coupling the production of reducing power for oxidative phosphorylation metabolism (OXPHOS) and antioxidant systems (Figure 1). This is an important mechanism as OXPHOS metabolism is a significant contributor to ROS production [74].

Beyond its role as a major coenzyme in energy molecules production, the oxidized form $\mathrm{NAD}^{+}$also acts as a co-substrate of several enzymes such as sirtuins (SIRT), ADPribose transferases (ART), poly-ADP ribose polymerases (PARPs), and the CD38 ADPribose cyclase that can impact the entire cellular homeostasis. We report readers to a more extensive review on the role of these pathways in the context of heart diseases [75]. Amongst these enzymes, the $\mathrm{NAD}^{+}$-dependent deacetylases (sirtuins), in particular, SIRT1 and SIRT3, control the acetylation status of many players of energy metabolism and are consequently major regulators of the cellular energy machinery [76]. For instance, SIRT1 deacetylates and activates the peroxisome-proliferator activated receptor gamma (PPARg) coactivator 1-alpha (PGC-1 $\alpha$ ), a major transcriptional regulator of metabolic genes and of the mitochondrial biogenesis program $[77,78]$. As a rise in $\mathrm{NAD}^{+} / \mathrm{NADH}$ ratio stimulates SIRT1 activity, it can be considered as a signaling molecule that participates in the intricate phenomena that coordinate energy demand and production. In contrast with its role as a coenzyme, $\mathrm{NAD}^{+}$is consumed as a substrate by all these signaling pathways (Sirtuins, PARPs, CD38) since it is irreversibly hydrolyzed in NAM and ADP-Ribose and NAD stores are only replenished by biosynthetic pathways. While homeostatic regulation presides the balance between $\mathrm{NAD}^{+}$hydrolysis and synthesis rates in physiological stages, these two processes sometimes do not match each other in pathological situations, in which a reduction in the steady-state level of $\mathrm{NAD}^{+}$often occurs due to increased activity of consuming enzymes that are not counterbalanced by increased synthesis rate.

In diet, Vitamin B3, mostly in the form of NAM, is found in fish, poultry, and cereals, but a majority of intakes comes from NAD that is hydrolyzed by enzymes at the intestinal brush border to produce NMN, NAM, and NR, as shown in studies on the rat intestine $[79,80]$. NA derived from gut microbiota-mediated deamidation of NAM could also be an important contributor to NAD homeostasis in the mammalian host [81]. NR enter cells via an equilibrative nucleoside transporter (ENT) family ENT1, ENT2, and ENT4 [82,83]; NA enters via organic anion transporter (OAT)2-mediated transport while NAM entry apparently depends on an unidentified solute carrier (SLC) [84]. As mentioned above, NMN may enter some cells through the SLC12A8 transporter [69] or after being dephosphorylated by CD73 to give NR $[85,86]$.

\subsection{Vitamin $B 5$}

Vitamin B5 (pantothenic acid) is important for energy metabolism since it is the precursor for Coenzyme A (CoA) biosynthesis [87]. As mentioned previously, CoA is 
required in the catabolism of all types of substrates owing to its function as an acyl group carrier (Figures 1 and 2). CoA is also needed for FA mitochondrial intake through CPT and for KB synthesis in the liver as well as for FA synthesis in the cytoplasm.

Pantothenic acid is found in a wide range of food. It is present in all plant and animal cells. It is found as CoA that is hydrolyzed to pantethine by an intestinal phosphatase before being split to pantothenic acid by an enzyme of the intestinal mucosa. Under this form, vitamin B5 is absorbed by enterocytes through the sodium-dependent multivitamin transporter (SMVT) [88]. Pantothenic acid is then distributed to all organs via the bloodstream since CoA cannot pass through biological membranes. Each cell has to produce its own CoA from pentatonic acid, cysteine, and ATP through a series of five intracellular reactions, or alternatively through degradation of dietary CoA by the ectonucleotide pyrophosphatase (ENPP) [89].

\subsection{Vitamin $B 6$}

Vitamin B6 refers to three distinct molecules (pyridoxal, pyridoxine, and pyridoxamine) leading to the active form of vitamin B6, namely pyridoxal phosphate (PLP). This compound is highly important for the maintenance of mitochondrial functions inasmuch as it is a cofactor of cysteine desulfurase complex which converts L-cysteine to L-alanine and provides the sulfur for iron-sulfur (Fe-S) cluster biosynthesis [90], an essential role of mitochondria that indirectly supports many cellular processes involving $\mathrm{Fe}-\mathrm{S}$ core proteins (Figure 3). Amongst the latter proteins, mitochondrial ETC complexes contain several Fe-S cores that participate in electron transfer [91,92], thereby placing PLP as a fundamental element for the establishment and maintenance of energy metabolism. This vitamin also acts as a cofactor of many transaminases required for amino acid metabolism [93], such as kynureninase involved in kynurenine-NAD pathways allowing de novo NAD production from tryptophan [94]. Regarding its roles in energy metabolism, PLP takes part in the folate cycle as a cofactor of serine hydroxymethyl transferase, which produces 5,10-methylenetetrahydrofolate [95], an important intermediate in the regeneration of methionine from homocysteine (an amino acid not used in protein synthesis) (Figure 2). Methionine is required for S-adenosyl-methionine, a molecule considered as the major methyl donor supporting protein methylation process, which impacts all cellular pathways, in particular those regulating energy metabolism (see sections "vitamin B9" and "vitamin B12" hereunder for further details) (Figure 2). This specific role of PLP, although well upstream of energy molecule production, makes this vitamin essential for cellular energetics. 


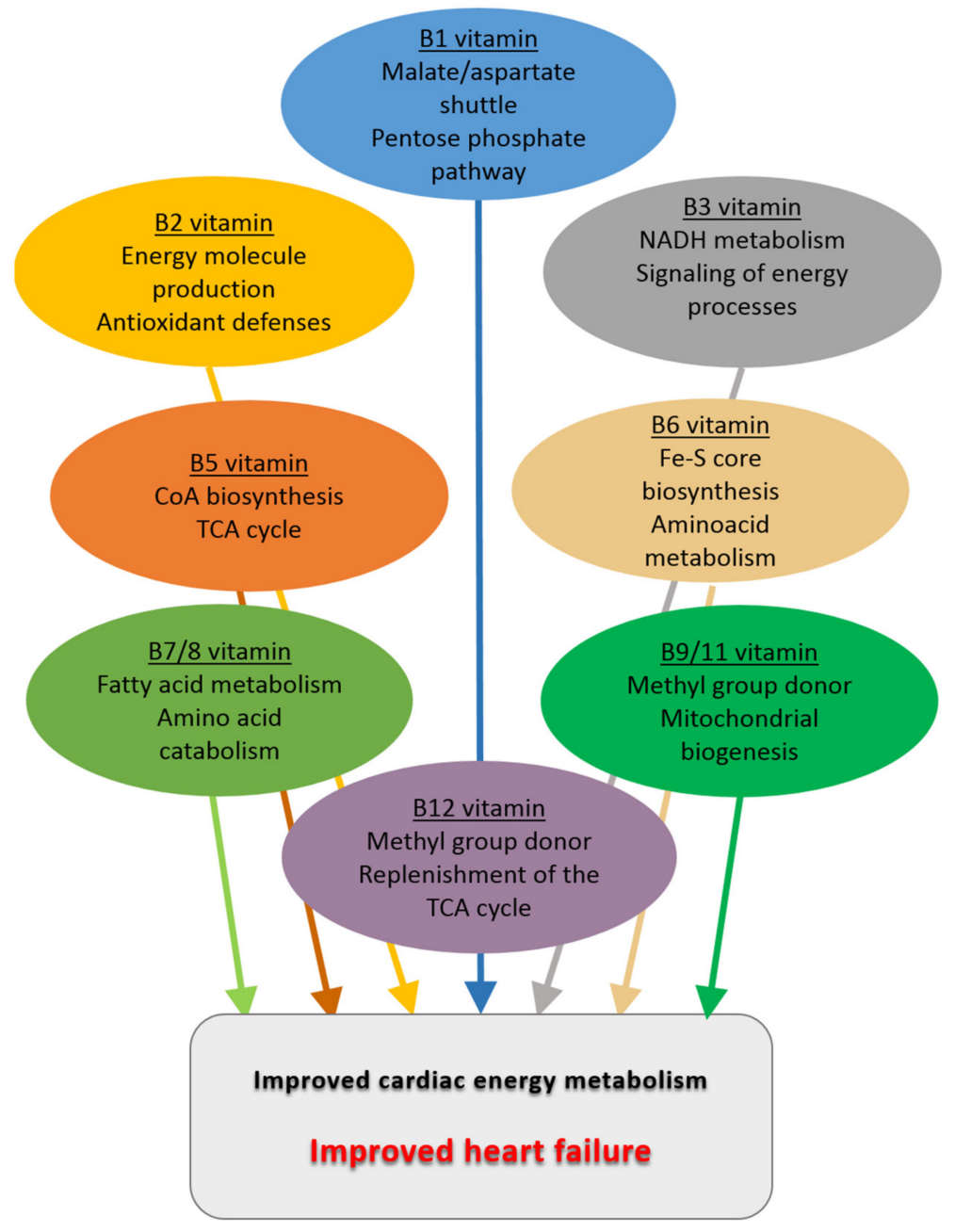

Figure 3. Main effects of B vitamins on energy metabolism and their potential benefits in heart failure.

In addition to its role in energy metabolism, PLP is involved in a number of pathways. Non-exhaustively, PLP is the cofactor of enzymes involved in cysteine synthesis [96], a proteinogenic amino acid, but also a precursor of glutathione (GSH), a cornerstone of cellular antioxidant systems [97] (Figure 2). The activity of aminolevulinate synthase, a mitochondrial decarboxylase stepping in heme synthesis, also needs PLP [98], placing this vitamin at the heart of the oxygen transport capacity in the blood.

In diet, PLP and its precursors are found in high amounts in vegetables, cereals, and muscle meats. In animal products, these vitamins are mainly present under the forms of PLP and pyridoxamine phosphate, while plant-derived products principally contain pyridoxine and pyridoxine phosphate [99]. These phosphorylated forms of B6 vitamins are hydrolyzed in the intestine prior to their absorption by brush border enterocytes [100]. Although it has long been described that entry of vitamin B6 into intestinal cells was ensured by passive diffusion [100], specific transporters of unphosphorylated B6 vitamines have been suggested since the 2000s [101,102].

\subsection{Vitamin $B 7 / 8$}

Vitamin B7/8 is known under the name of biotin, which is a prosthetic group of five cellular carboxylases in humans (acetyl-CoA carboxylase 1 and 2 (ACC1, ACC2), propionyl-CoA carboxylase (PCC), 3-methylcrotonyl-CoA carboxylase (MCC), and pyruvate carboxylase (PC)), four of which are located at the outer membrane or in the matrix of mitochondria [103]. Interestingly, all these enzymes are involved in energy metabolism. ACC1 and ACC2 produce malonyl-CoA from acetyl-CoA. While ACC1 is mainly located in 
the cytosol of lipogenic tissue cells (liver and adipose tissue) and its malonyl-CoA product allows biosynthesis of long-chain fatty acids, ACC2 is highly expressed in the heart and skeletal muscle where it is bound to the outer mitochondrial membrane. There, it modulates mitochondrial long-chain acyl-CoAs uptake [104], as malonyl-CoA is a potent inhibitor of CPT1 preventing FAs influx into mitochondria and subsequent $\beta$-oxidation [105]. PCC, MCC, and PC are all located in the mitochondrial matrix. PCC and MCC enzymes regulate critical steps of amino acid catabolism (and odd-chain FAs for PCC) by respectively producing methylmalonyl-CoA from propionyl-CoA for the catabolism of isoleucine, methionine, valine and threonine [106] (Figure 1), and 3-methylglutaconyl-CoA from 3-methylcrotonyl-CoA for leucine and isovaleric acid catabolism [107]. PC also converts pyruvate to oxaloacetate that can be used to replenish the TCA cycle or for the initiation of gluconeogenesis (in liver and kidney) or lipogenesis (adipose tissue, liver as well as brain) [107].

Biotin is found in diet under its active form, which does not undergo further chemical modification within the organism. The main sources of biotin are liver, egg yolk and soybeans; this vitamin is taken up by enterocytes via the same SVMT system as pantothenic acid [88].

\subsection{Vitamin $B 9 / 11$}

Vitamin B9/11, better known under the name of folate, is involved in a wide variety of chemical reactions. It has originally been identified in the 1930s as an essential nutrient to reduce anemia during pregnancy due to its role in erythropoiesis [108]. Later, it was described as a cofactor of many enzymes participating in various processes such as purine synthesis and methylation reactions [109] (Figure 2). Although folate metabolism is quite intricate, a thorough analysis of the folate cycle reveals clear links between this vitamin and energy metabolism. In mammals, folate acts in the form of many derivatives, which are cofactors that accept or donate one-carbon units ( $1 \mathrm{C}$ metabolism) and are participants in energy molecule production. Amongst these compounds, 5-methyl-THF and 5,10methyleneTHF play key roles insomuch as they orientate folate metabolism towards specific metabolic pathways (Figure 2). It is important to state that two separate folate cycles coexist in the cell, one in the cytosol and one in the mitochondria with different isoforms of 5,10methylene-THF dehydrogenases (MTFHR) (Figure 2). In the cytosol, the cycle leads to serine synthesis due to the very high NADPH/NADP ${ }^{+}$ratio since NADP is the coenzyme of cytosolic MTHFD1. In the mitochondria, the folate cyle leads to serine catabolysis because the mitochondria MTHFD2/L and MTHF1L can use NAD as a coenzyme and the $\mathrm{NAD}^{+} / \mathrm{NADH}$ ratio is high in the mitochondrial matrix. For a detailed review on $1 \mathrm{C}$ metabolism, see the review by Ducker and Rabnowitz [110]. The two cycles communicate through the shuttling of reduced THF from the cytosol to mitochondria and the excretion of oxidized formate from mitochondria to cytosol.

The 5-methyl-THF form of the vitamin is used as a methyl-donor to generate methionine from homocysteine in a reaction catalyzed by methionine synthase [111], allowing the regeneration of methionine which is then adenylated to produce S-adenosylmethionine (SAM) (Figure 2). In humans, mitochondrial-derived formate seems to be the primary source of one-carbon units derived from serine catabolysis for remethylation of homocysteine [112]. SAM is considered as the universal donor of methyl groups in methylation reactions consisting in methylation of DNA, RNA, and proteins [113]. More than a hundred cellular compounds can be subjected to this methylation process, including important regulators of energy metabolism such as PGC- $1 \alpha$ or SIRT1. Indeed, PGC- $1 \alpha$ can be methylated and activated by protein arginine methyltransferase 1 (PRMT1) [114], while the expression and/or activity of SIRT1 could be directly or indirectly impacted by these transmethylation reactions [115]. This clearly confers an important role to folate in cellular energetics. It is noteworthy that methionine is also required for GSH synthesis, and, in this sense, folate is an important element of the cell's antioxidant defenses especially as this vitamin acts as a direct antioxidant and scavenger molecule [116]. The 5,10-methyleneTHF form, for 
its part, is used for thymidylate and purine synthesis [109]. For this reason, folate is not only essential for cellular proliferation but also for ATP production that requires prior synthesis of adenine, a purine nucleobase. In addition, 10-formyl-THF is used for the formylation of mitochondrial initiator methionine tRNAs that is required for translation of mitochondrially encoded proteins [117].

Folate is abundant in green vegetables, oranges, eggs, or unprocessed grains (a daily intake of $0.4 \mathrm{mg}$ is recommended). It is mostly present in the reduced form in the human diet, typically 5-methyl-THF [118]. In diet, it is mostly bound to proteins as polyglutamates that must be hydrolyzed by proteases before being absorbed in the small intestine. Folate uptake into enterocytes of brush-border requires the presence of specific transporters such as proton-coupled folate transporter (PCFT), the mutation of which has been identified as a cause of hereditary folate malabsorption [119].

\subsection{Vitamin B12}

Vitamin B12, namely cobalamin (Cbl), exhibits a quite complex structure when compared with the others B vitamins. It is required as a cofactor of cytosolic and mitochondrial enzymes that are directly or indirectly involved in energy metabolism. In the cell, $\mathrm{Cbl}$ is transformed into methylcobalamin and adenosylcobalamin, which are respectively found in the cytosol and in the mitochondria [120]. Methylcobalamin acts as a cofactor in the reaction catalyzed by methionine synthase in which it plays, similar to 5-methylTHF, the role of methyl group carrier to support the conversion of homocysteine to methionine [113] (Figure 2). Owing to this role in methionine synthesis, cobalamin is at the origin of the methylation process and GSH production in a similar way as folate. Adenosylcobalamin, under the form of deoxyadenosylcobalamin, is a cofactor of methylmalonyl-CoA mutase, which converts methylmalonyl-CoA, derived from carboxylation of propionyl-CoA, to succinyl-CoA within the mitochondrial matrix [121] (Figure 1). This pathway is important for the degradation of amino acids (valine, isoleucine, and methionine) and metabolites of odd-chain fatty acid, allowing replenishment of the TCA cycle from these sources.

The main sources of $\mathrm{Cbl}$ are organ meats, milk (and milk products), and shellfish so that strict vegetarians need to take $\mathrm{Cbl}$ as a supplement, although the daily recommended intake is a few $\mu \mathrm{g}$. The highly acid gastric environment plays a key role in $\mathrm{Cbl}$ absorption as acidity and pepsin allow $\mathrm{Cbl}$ release contained in food. $\mathrm{Cbl}$ then binds to intrinsic factor (IF) produced and secreted by acid-secreting parietal cells of the stomach [122]. The IF-Cbl complex is absorbed in the distal ileum via the receptor for IF-Cbl, cubilin [123].

\section{Alterations of Energy Metabolism in Heart Failure}

Drastic alterations of energy metabolism have largely been reported in the pathophysiology of HF and are now thought to be a key element of the progression of the disease. Although metabolic phenotype in HF can perceptibly vary according to etiology and HF stage as alterations progressively set in [124], studies in human and animal HF models revealed typical metabolic alterations in advanced HF. Amongst these alterations, the metabolic switch from FA utilization to carbohydrate metabolism, which consumes less oxygen to produce ATP, has extensively been described in the last decades [125,126].

While FA oxidation would not be systematically affected at the early stage of HF (depending on the model) $[127,128]$, advanced and end-stage HF are clearly characterized by a strong decrease in FA utilization, especially due to the down-regulation in FA oxidation enzyme expression (LDAC and MCAD especially) shown in animal HF models and human $[129,130]$. The mechanisms at the origin of these dysregulations in HF are still not completely understood, but they undoubtedly involve a reduction in the protein level of PPAR $\alpha$ [131] and its transcriptional co-activator PGC-1 $\alpha$ [132], as PPAR $\alpha$ plays a pivotal role in regulating the expression of genes encoding actors of mitochondrial $\beta$-oxidation and FA transport [133]. This alteration of FA metabolism regulators is a part of the so-called fetal reprogramming that is a well-known hallmark of HF [134] and is characterized by a switch of substrate preference of cardiomyocytes to carbohydrates, as is the case in the 
immature heart [135]. The increase in carbohydrate utilization as an alternative source of ATP production seems to be an earlier event than the decrease in FA oxidation in the progression of cardiac diseases to HF since studies report higher capacities to use glucose as soon as compensated cardiac hypertrophy stage $[136,137]$. The underlying mechanisms initiating the stimulation of carbohydrate catabolism processes are still not perfectly understood, although AMPK, the energy stress sensor kinase, could play a determinant role in this phenomenon [138].

The utilization of glucose is beneficial and improves the efficiency of the heart as long as cardiac oxidative capacities allow glucose oxidation [139]. However, as HF evolves, alterations of mitochondrial functions [3] and modulations of pyruvate metabolism (probably due to changes in PDH activity/expression, pyruvate transport and NADH shuttle [140]) occur and lead to a stage in which this switch is no longer adapted to support suitable energy production. Finally, the increase in the capacities of the cardiomyocytes to produce energy from glucose is only transitory [128]; the worsening of HF is actually associated with a decrease in energy production from glucose owing to major dysregulations such as alterations of mitochondrial machinery, i.e., TCA cycle and oxidative phosphorylations [141]. This results in the loss of the coupling between glycolysis and glucose oxidation which is required for efficient use of this substrate [9]. A general decrease in mitochondrial mass and mitochondrial biogenesis also contributes to the decreased oxidative capacity in the failing heart, partly due to the decrease in PGC-1 $\alpha$ and its transcription cascade [132]. Interestingly, glycolytic enzymes expression has also been reported to be decreased in an animal at the advanced stage of HF [142], suggesting that global alteration of glucose catabolic processes takes part in the collapse of cardiomyocyte energy metabolism and in the energetic distress of the failing myocardium. As a result, at the end-stage, the failing heart contains about $30 \%$ less ATP than a healthy heart and also exhibits a lower PCr content [143], PCr being generated by creatine kinase from ATP and acting as an energy storage molecule and an energy transport compound (for further details see [144]).

The defects in mitochondrial functions, in particular in oxidative capacities, are major causes of energy deficit in HF. These alterations are the consequences of combined phenomena such as compromised mitochondrial biogenesis and increased reactive oxygen species (ROS) production by mitochondrial electron transfer chain. HF is indeed associated with profound perturbations of mitochondrial life cycle partly due to down-regulation of PGC- $1 \alpha$ and its downstream target genes, which control the renewal of the mitochondrial pool of cardiomyocytes [132], thereby leading to the accumulation of mitochondrial defects reported in the failing myocardium. As the quality of the mitochondria decreases, these organelles produce more and more ROS, such as superoxide and hydrogen peroxide, that alter the structural component of the cardiac cell and precipitate the cellular damage [145].

\section{B Vitamins in Heart Failure}

It is now well accepted that patients with HF present micronutrient deficiencies owing to malabsorption resulting from splanchnic congestion, increased urinary loss of nutrients caused by diuretics largely used in HF treatment, as well as a poor oral intake at advanced stages of HF [146-148]. These last decades, the micronutrient status of HF patients has been the subject of many studies, and it has been shown in particular that B vitamins deficiency has been found to be more prevalent in HF patients than in the general population [23,149]. This has been described almost for the whole family of B vitamins, and one can reasonably think that a deficiency in one or more of these vitamins could participate in the deficit of energy production reported in HF. This is why many research teams have suggested that the addition of supplementation with specific B vitamins to standard HF therapies could be beneficial and could potentially help to preserve the cardiac function of HF patients longer. As several B vitamins are at the heart of many energy metabolism processes, it is thus conceivable that the use of certain vitamins could be beneficial to support the activity of the failing heart even in patients with no specific deficiency as these vitamins could play a role in boosting particular metabolic pathways to restore the energy balance of the 
myocardium. Beyond their potential impacts on energy metabolism, the use of B vitamins could also be interesting in the context of cardiovascular disease owing to their effects on the vascular system and atherosclerosis [150].

\subsection{Vitamin B1}

Thiamine deficiency in HF has been regularly reported $[14,151,152]$ and could reach about $90 \%$ of hospitalized HF patients receiving furosemide [153,154], a loop diuretic which is thought to participate in this deficiency $[155,156]$, although this hypothesis has not been systematically confirmed in trials [151]. It is difficult to accurately assess the rate of thiamine deficiency in HF as the available data comes from studies with very specific designs, including different HF populations (age range, medications, underlying nutrition status ... ). The fact that a significant proportion of the general HF population is affected by this deficency, and that mitochondrial energy production function is intimely related to thiamine, gives weight to the hypothesis that this vitamin could be useful in HF therapy.

The effects of thiamine or benfotiamine (a thiamine prodrug with high bioavailability) on the progression of cardiovascular diseases have been largely studied for twenty years. Using animal models, it has been clearly shown that these compounds protect the function of the heart facing stress such as ischemic injury [157], myocardial infarction [158,159], or doxorubicin cardiotoxicity [160]. It has also been suggested that vitamin B1 would be particularly efficient to prevent diabetes-induced diastolic dysfunction in type 1 and type 2 diabetic mice [161]. Interestingly, the benefit of vitamin B1 supplementation on cardiac function would especially rely on the reduction of oxidative stress $[158,159,162]$ as well as the preservation of mitochondrial functions $[157,163]$. As mentioned above, mitochondrial defects and dysregulation of ROS production/detoxification are major alterations in the failing myocardium; it thus confers credit to the use of thiamine and/or its derivatives to treat HF. Incidentally, the benefits of thiamine supplementation in HF treatment have been assessed in small groups of patients. Several trials, including a maximum of a few tens of HF patients, supplemented with thiamine (dose ranging from $100 \mathrm{mg}$ to $300 \mathrm{mg}$ per day), reported a significant increase in left ventricular ejection fraction after several weeks of supplementation $[153,164,165]$. Whereas the trial led by Seligmann et al. in the nineties showed that the beneficial effect of thiamine on left ventricular ejection fraction was associated with better functional capacity (improved by at least one NYHA class) [153], it was confirmed in a more recent study by Schoenenberger et al. in which no change in walking time was observed in patients with improved left ventricular ejection fraction after thiamine supplementation period [165]. This raises questions about the real usefulness of thiamine supplementation in HF therapy, especially as other trials failed to demonstrate any benefit of vitamin B1 (dose ranging from $100 \mathrm{mg}$ to $300 \mathrm{mg}$ per day) although thiamine circulating level increased [15,166-168]. These studies not only failed to show a beneficial effect on cardiac function (FE) $[15,167]$ but also failed to show an improvement in the quality of life of HF patients [15,166-168]. So far, the evaluation of thiamine supplementation as a new tool in HF therapeutics has shown mixed results and conclusions from the aforementioned studies are not clear because of the small sample size, short duration of follow-up, lack of any dietary assessment of thiamine intake, as well as the lack of precisely defined inclusion criteria. This does not lead to the recommandation for the routine use of thiamine therapy in general HF population but larger trials should be led to clearly state.

\subsection{Vitamin B2}

The rare assessments of riboflavin status in patients with HF suggest that the prevalence of vitamin B2 deficiency would be higher in this population [23,146,149], especially due to lower intake $[169,170]$. However, to our knowledge, no trial was specifically designed to study the effects of riboflavin supplementation in HF patients or even to understand the potential links between this deficiency and cardiac dysfunction. In elderly HF patients, this vitamin has actually been tested as part of micronutrient supplementation, 
including fifteen compounds (vitamins and minerals) [171]. While this cocktail significantly improved the left ventricular function of the heart in those patients, it would be speculative to suggest a beneficial effect of riboflavin at this point.

The most convincing results suggesting that riboflavin may be beneficial/protective for cardiac function have been obtained in animal models. Riboflavin has been shown to alleviate myocardial hypoxic/ischemic injury in mice via the activation of lysine-specific demethylase 1 (LSD1), which requires FAD to ensure its epigenetic modification function [172]. In this study, the authors reported that riboflavin supplementation increased FAD production/levels in vivo. Given the importance of flavoprotein in energy metabolism, the administration of riboflavin for its role as a FAD precursor could be useful to support energy production in situations of energy distress such as HF. Although the physiological importance of FAD, in particular in cardiac metabolism, has been overlooked in comparison with NAD, FAD could yet be of great interest to restore energy metabolism. For instance, it has been demonstrated that FAD stabilizes mitochondrial acyl-CoA dehydrogenases (SCAD and MCAD) activity in vitro [173]. In spontaneously hypertensive rats, treatment with FAD inhibited pathological cardiac hypertrophy and fibrosis and these effects were associated with a significant increase in SCAD activity, higher ATP content, and a decrease in ROS level [174], thereby suggesting a cardiac protective effect of this compound that should be considered at least to hinder the progression of cardiovascular diseases to HF. Riboflavin has also proven its abilities to protect cardiac function in a rat model of type 1 diabetes induced by streptozotocin in which the oral administration of riboflavin preserved myocardial function and improved heart antioxidant status [175].

To date, there is a clear lack of strong evidence to determine if riboflavin could be useful to treat HF patients, but the limited data available in the literature suggest a cardioprotective role in animals and must prompt further investigations.

\subsection{Vitamin $B 3$}

In the last decade, a number of studies in rodent models of HF including myocardial infarction (MI) triggered by experimental ligature of the left coronary artery, pressureoverload hypertrophy triggered by experimental transverse aorta constriction (TAC), or genetic models of cardiomyopathy showed that NAD homeostasis is altered in the failing heart. The findings either showed a decrease in the $\mathrm{NAD}^{+} / \mathrm{NADH}$ ratio in the context of TAC or complex I deficiency due to accumulation of NADH $[176,177]$ or a decrease in the global pool of NAD (i.e., the sum of $\mathrm{NAD}^{+}$and NADH pools) [178-181]. Even in recently developed models of HF with preserved ejection fraction (HFpEF), NAD homeostasis appears to be altered [182,183]. At least one study reported a similar $30 \%$ decrease in NAD levels in failing human hearts from DCM patients [184]. The cause for the drop in the myocardial NAD level is not clearly understood and could vary depending on the model. It is potentially due to more active $\mathrm{NAD}^{+}$-signaling pathways that cleave the NAD molecules and that are activated by energy and oxidative stress (e.g., SIRT1, PARP1). However, cardiac expression of the nicotinamide phosphoribosyl transferase (NAMPT) is also almost systematically repressed in HF models and could lead to deficient NAD biosynthesis [185,186]. Interestingly, the alternative NAD synthetic pathway mediated by nicotinamide riboside kinase 2 (NMRK2) appears to be upregulated to compensate for the drop of NAMPT expression, especially in mouse DCM models [179,186]. This striated muscle-specific kinase has been described to be essential to maintain NAD levels in the murine aged heart [187].

In all the studies cited above, supplementation of conventional rodent diet with therapeutic doses of diverse forms of vitamins B3 (NR, NAM, or NMN ranging from 200 to $400 \mathrm{mg} / \mathrm{kg}$ of body weight/day) resulted in increased myocardial NAD levels, beneficial outcome in terms of survival and improvement of ejection fraction in models of $\mathrm{HF}$ with reduced ejection fraction (HFrEF) or diastolic parameters in HFpEF. In most but not all of the preclinical studies, boosting NAD levels were also associated with improved mitochondrial oxidative capacities in the heart. Other mechanisms linked to the $\mathrm{NAD}^{+}-$ 
dependent signaling pathways probably play important roles in these beneficial effects, and the precise molecular mechanisms remain to be better explained.

Altogether these positive effects have been raising hope for bench-to-bed transfer and clinical applications $[75,188,189]$. A few pilot phase $1 / 2$ trials assessing the effect of NR supplementation (2000 mg/day) on systolic HF patients have been completed (e.g., NCT03423342, First Posted: 6 February 2018 and NCT03727646, First Posted: 1 November 2018 at https:/ / clinicaltrials.gov), but results regarding the HFs symptoms were not published yet at the time of this review. Of note, NR administration was reported to suppress inflammatory activation of peripheral blood mononuclear cells (PBMCs) in HF, thereby suggesting that beyond targetting NAD deficiency in the failing heart, NR treatment may have interesting systemic effects [190].

\subsection{Vitamin B5}

Despite the importance of pantothenic acid in acetyl-CoA biosynthesis and consequently in metabolism, this vitamin is not routinely measured in patients, so that there is no data on the prevalence of pantothenic acid deficiency in HF patients. Incidentally, vitamin B5 supplementation in the context of heart disease has apparently not been investigated largely even in multi-micronutrient supplementation studies. Yet, during the 1990s, a young boy affected by a dilated cardiomyopathy due to type $2 \mathrm{X}$-linked 3-methylglutaconic aciduria was treated with pantothenic acid that showed impressive positive effects on heart function [191], demonstrating the therapeutic potential of this compound in particular conditions.

A handful of studies looked at the effect of this vitamin on cardiac function in animal models inducing cardiac stress. In rats, dexpanthenol, a precursor of pantothenic acid, is beneficial for the heart during sepsis induced by cecal ligation and puncture [192] and could also protect the heart from isoproterenol-induced cardiac damage [193]. This protection could rely on the preservation of antioxidant machinery that would maintain a better antioxidant status of the myocardium; a mechanism already suggested to explain the protective effect of dexpanthenol on cardiovascular damage, especially on endothelial dysfunction, in the type 1 diabetes rat model [194]. Seemingly, vitamin B5 has not really been considered as a potential stimulator of energy metabolism in the context of diseases in which major alterations of energy production have been described; this question remains open for further research.

\subsection{Vitamin $B 7 / 8$}

To the best of our knowledge, HF has not been associated with a high prevalence of biotin deficiency, and no study has investigated the potential benefit of biotin supplementation in cardiac diseases. The understanding of the role of biotin in various disease states is quite limited [23]. Although cardiac tissue seemed to be relatively insensitive to biotin deficiency in rats [195], the role of this vitamin as a prosthetic group of several key enzymes of energy metabolism suggests that this compound and its role in HF pathophysiology deserves more attention and should be the subject of further investigations.

\subsection{Vitamin B6, Vitamin B9 and Vitamin B12}

Pyridoxine, folate and cobalamin have largely been studied for their roles in homocysteine metabolism, and, for this reason, they have often been used together to test their benefits in the treatments of pathologies associated with hyperhomocysteinemia (HHCY) [196-198]. HHCY has been reported in HF regardless of its etiology [199,200], and circulating homocysteine level is related to clinical variables of HF [201,202], thereby suggesting a link between this compound and the clinical status of the patients. HHCY is generally caused by a deficiency in vitamin B6, B9, and/or B12 [198,203,204]. Although HHCY has clearly been described in HF, deficiency in these vitamins are under question. It seems that pyridoxine level would be decreased in HF patients $[149,205]$, but folate and cobalamin deficiency would be relatively rare [206], and these vitamins would not be 
related to the severity of the disease [201]. However, a recent study reported a subclinical cobalamin deficiency associated with increased serum methylmalonic acid in HF and suggests that vitamin B12 deficiency might have been underestimated in previous clinical studies [203]; these data should be confirmed by larger studies. HHCY in HF could also be a consequence of kidney dysfunction associated with HF [207] since this organ is responsible for homocysteine clearance. Reduced urinary homocysteine excretion can be a cause of homocysteinemia elevation when folate and cobalamin levels are normal [208]. Whatever the cause of HHCY in HF, it could be part of the mechanisms leading to the alteration of the general condition of HF patients. Deleterious effects of $\mathrm{HHCY}$ on cardiac function could be indirect as a high level of homocysteine is known to affect the vascular system. For instance, it induces endothelial cell dysfunction and modulates vascular smooth muscle cells contractility. This can especially be explained by the fact that HHCY leads to the inhibition of nitric oxide synthesis [209], increases ROS production [210] and stimulates matrix metalloproteinase activity [211] in endothelial cells as well as enhances collagen production by smooth muscle cells [212]. These dysfunctions probably participate in the well-known development of atherosclerosis in patients with high homocysteinemia that presents $\mathrm{HHCY}$ as an independent risk factor for atherosclerosis [213]. In addition to its atherothrombotic effect, $\mathrm{HHCY}$ could also directly affect cardiac function. In animals, diet-induced HHCY has been shown to induce important myocardial collagen deposition associated with diastolic dysfunction in hypertensive rats [214] or ventricular (left and right) hypertrophy with increased perivascular and interstitial collagen as well as myocardial mast cell infiltration in normotensive rats [215]. It has even been demonstrated using coronary-perfused hearts that homocysteine elicited a concentration-dependent negative inotropic action that was partially antagonized by a non-selective antagonist of adenosine receptor $[216,217]$.

Owing to HHCY effects on vessels and the evidence suggesting that HHCY contributes to the development of cardiovascular diseases, homocysteine-lowering interventions have been proposed to prevent cardiovascular events, especially stroke and myocardial infarction. Thus, many studies consisted in giving vitamin B6, B9, or B12 (alone or in combination) to adults at risk of or with established cardiovascular disease these last two decades. Generally, these studies and post hoc meta-analysis failed to demonstrate clear beneficial effects of these vitamins on cardiovascular events whatever the vitamin combination, although the administration of pyridoxine, folate, and/or cobalamin often significantly lowered homocysteine levels $[113,197,218,219]$. On the other hand, a study led by Towfighi et al. showed that, after stratifying the treated population by age, vitamin supplementation was associated with reduced risk of stroke and myocardial infarction in patients older than 69 [220], suggesting that older patients are more likely to benefit from this B vitamin therapy. Another meta-analysis including studies testing supplementation with folate alone demonstrated that it slightly reduced the risk of stroke and CVD, with more reduction for the risk of CVD in patients without preexisting CVD or with a large decrease in homocysteine levels [221]. This beneficial effect of folate on the risk of stroke has been confirmed by a recent meta-analysis that, however, mentioned that folate supplementation did not reduce the risk of coronary heart disease [222]. Whereas these conflicting results did not lead to clear recommendations to use these vitamins in patients, it seems that even if the effect of these three vitamins on the prevention of cardiovascular events is not fully established; they could be of great value to treat patients with specific profiles that have to be determined by further studies.

To our knowledge, this homocysteine-lowering strategy has not been tested in patients with established HF. Given the prevalence of HHCY in HF and the deleterious effects of $\mathrm{HHCY}$ on cardiac function, it is surprising that this kind of study has never been considered and that data related to the effects of these vitamins in HF are lacking. Besides, the use of these vitamins in animal models of cardiac dysfunction highlighted other actions of these compounds, suggesting that they could be useful to preserve heart function independently of their homocysteine-lowering effect. For instance, folate has been shown to protect cardiac 
function in mice subjected to myocardial infarction [223], doxorubicin [224], celecoxib [225], high fat diet-induced obesity [226], and would also prevent age-related cardiac remodeling [227]. It could act through the normalization of metalloproteinase inhibitor levels [223], modulation of endothelial nitric oxide synthase [224], or the reduction of cardiac oxidative stress [226]. Its beneficial effects in old mice would especially be related to the modulation of ER stress pathway, which is usually upregulated in the aged heart [227]. Folates would protect diastolic function and decrease overall myocardial collagen deposition in a rat model of hypertrophy induced by monocrotaline [228]; its antioxidant properties could play an important role in the protective effect of folate in this model [229]. Cobalamine has been identified among activators of the PGC1 $\alpha$, a regulator of mitochondrial biogenesis and genes related to FAO and glycolysis, as mentioned previously [230]. A combination of folate and cobalamin has also been successfully used in rodents, in which it reduced cardiac damage in a model of isoproterenol-induced myocardial infarction in rats with HHCY [231], proving the ability of such supplementation to lower homocysteine levels with subsequent protection of the heart. A recent study testing the effects of folate and cobalamin supplementation in a mouse model of heart failure induced by pressure overload showed that left ventricle ejection fraction was preserved in mice fed with food supplemented with folate and cobalamin [232]. Interestingly, this was associated with a preservation of mitochondrial function that could be due to a minimized alteration of the mitochondrial biogenesis process. The underlying mechanisms would involve the role of folate and cobalamin in S-adenosylmethionine production which could then support methylation reactions that would stimulate PGC- $1 \alpha$ activity in this model. Beyond the fact that this study showed that a supplementation with folate and cobalamin was beneficial for the heart facing pressure overload, the preservation of energy metabolism described in this work suggests that B vitamins could be part of a metabolic therapy of HF. Nowadays, the use of these vitamins in HF patients is not really considered because of the lack of convincing data in human. However, the improvement of endothelial function in cardiac transplant recipients and $\mathrm{HF}$ patients receiving pyridoxine and folate supplementation, respectively, demonstrate the benefit of these vitamins on the cardiovascular system in pathology $[233,234]$.

All the above-mentioned preclinical and clinical studies and the main effects of B vitamins that could be beneficial in the context of heart failure are summarized in Table 1 and Figure 3, respectively.

Table 1. B vitamin supplementation and cardiovascular diseases in animals and humans.

\begin{tabular}{|c|c|c|c|}
\hline Vitamin & Specie & Effects & Studies \\
\hline \multirow{14}{*}{ B1 } & & Positive effects on cardiac function: & \\
\hline & Mice & - myocardial infarction & [158] \\
\hline & & - diabetes-induced cardiac dysfunction & [161] \\
\hline & \multirow{5}{*}{ Rat } & Positive effects on cardiac function: & \\
\hline & & - ischemic injury & [157] \\
\hline & & - myocardial infarction & [159] \\
\hline & & - doxorubicin cardiotoxicity & [160] \\
\hline & & - diabetes-induced cardiac dysfunction & [163] \\
\hline & \multirow{6}{*}{ Human } & Supplementation (100 to $300 \mathrm{mg} /$ day) in HF patients: & \\
\hline & & - increase in left ventricular ejection fraction & {$[153,164,165]$} \\
\hline & & - better functional capacity (NYHA class) & [153] \\
\hline & & - no change in walking time & [165] \\
\hline & & - no benefit on cardiac function (FE) & {$[15,167]$} \\
\hline & & - no improvement in the quality of life & {$[15,166-168]$} \\
\hline
\end{tabular}


Table 1. Cont.

\begin{tabular}{|c|c|c|c|}
\hline Vitamin & Specie & Effects & Studies \\
\hline \multirow{3}{*}{$\mathrm{B} 2$} & Mice & $\begin{array}{l}\text { Supplementation with riboflavin: reduction of myocardial } \\
\text { ischemic injury }\end{array}$ & [172] \\
\hline & Rat & $\begin{array}{l}\text { FAD treatment decreases cardiac hypertrophy and fibrosis in } \\
\text { SHR rats } \\
\text { Supplementation with riboflavin: protect heart function } \\
\text { (type1 diabetes) }\end{array}$ & $\begin{array}{l}{[174]} \\
{[175]}\end{array}$ \\
\hline & Human & $\begin{array}{l}\text { Supplementation with a cocktail of vitamins and minerals, } \\
\text { including riboflavin: improvement of ventricular function }\end{array}$ & [171] \\
\hline \multirow{8}{*}{ B3 } & \multirow{8}{*}{ Mice } & $\begin{array}{c}\text { Supplementation with NMN } \\
\text { - preserves of cardiac mitochondrial function in complex-I } \\
\text { deficient mice exhibiting accelerated HF in response to } \\
\text { chronic stress }\end{array}$ & [176] \\
\hline & & $\begin{array}{c}\text { - delays the development of HF in mice with } \\
\text { mitochondrial dysfunction }\end{array}$ & [177] \\
\hline & & Supplementation with NR & \\
\hline & & - preserves cardiac function in Srf mutation induced-DCM & [179] \\
\hline & & - preserves cardiac function in Lmna mutation induced-DCM & [180] \\
\hline & & $\begin{array}{l}\text { - improves cardiac mitochondrial function and ameliorates } \\
\text { HFpEF phenotype }\end{array}$ & [183] \\
\hline & & $\begin{array}{c}\text { Supplementation with nicotinamide improves diastolic } \\
\text { dysfunction induced by aging }\end{array}$ & [182] \\
\hline & & Exogenous NAD blocks cardiac hypertrophy response & [235] \\
\hline \multirow{3}{*}{ B5 } & Rat & $\begin{array}{l}\text { Supplementation with nicotinamide improves diastolic } \\
\text { dysfunction induced by hypertension or } \\
\text { cardiometabolic syndrome }\end{array}$ & [182] \\
\hline & Human & $\begin{array}{l}\text { oral NR administration: improvement of PBMC respiration } \\
\text { and reduced proinflammatory cytokine gene expression in } \\
\text { patients with HF }\end{array}$ & [190] \\
\hline & Rat & $\begin{array}{l}\text { Treatment with dexpanthenol, a vitamin B5 precursor: } \\
\text { - protection of the heart during sepsis } \\
\text { - protection heart from isoproterenol-induced damage } \\
\text { - beneficial effects on endothelial function (type } 1 \text { diabetes) }\end{array}$ & $\begin{array}{l}{[192]} \\
{[193]} \\
{[194]}\end{array}$ \\
\hline \multirow{3}{*}{$\mathrm{B} 6 / \mathrm{B} 9 / \mathrm{B} 12$} & Mice & $\begin{array}{c}\text { Folate supplementation protects cardiac function: } \\
\text { - myocardial infarction } \\
\text { - doxorubicin cardiotoxicity } \\
\text { - high-fat diet-induced obesity } \\
\text { Supplementation with folate and cobalamin: Preservation of } \\
\text { left ventricular ejection fraction (pressure overload } \\
\text { induced-HF) }\end{array}$ & $\begin{array}{l}{[223]} \\
{[224]} \\
{[226]} \\
\\
{[232]}\end{array}$ \\
\hline & Rat & $\begin{array}{l}\text { Folate supplementation protects cardiac function: celecoxib } \\
\text { cardiotoxicity } \\
\text { Folate supplementation protects diastolic function and } \\
\text { prevents fibrosis: monocrotaline-induced hypertrophy } \\
\text { Supplementation with folate and cobalamin: reduction of } \\
\text { cardiac damage (isoproterenol-induced infarction) }\end{array}$ & $\begin{array}{c}{[228,229]} \\
{[231]}\end{array}$ \\
\hline & Human & $\begin{array}{l}\text { Supplementation with B6/B9/B12: decrease in risk of stroke } \\
\text { and myocardial infarction in patients older than } 69 \\
\text { Supplementation with folate: } \\
\text { - decrease in risk of stroke } \\
\text { - decrease in risk of CVD in patients without preexisting CVD } \\
\text { Pyridoxine: improvement of endothelial function (cardiac } \\
\text { transplant recipients) } \\
\text { Folate: improvement of endothelial function (HF patients) }\end{array}$ & $\begin{array}{c}{[221,222]} \\
{[222]} \\
{[233]} \\
{[234]}\end{array}$ \\
\hline
\end{tabular}




\section{Conclusions}

Alterations of cardiac energy metabolism are clue factors in the etiology of heart failure. We have presented ample evidence that B vitamins are important factors involved at all levels of the regulation of cardiac energy metabolism. This review of the literature shows that $B$ vitamins potentially present great interest in the regulation of cardiac energy metabolism and thus treatment of cardiovascular diseases. Studies in animals have shown that these vitamins have beneficial effects on cardiac energy metabolism and thus cardiac function. Today their use in humans in the context of heart failure is hampered by the inconclusive results of low-power clinical studies, whose design was more often oriented toward prophylactic measures of risk reduction rather than a therapeutic approach despite studies showing an improvement of cardiac function and/or the quality of life of the patients. However, certain vitamins were never even tested within the precise context of HF. In view of the positive results mentioned above and their importance in cardiac energy metabolism, it seems that vitamins could be useful in patients whose profile remains to be defined. Advanced age and malnutrition will be important but not the sole criteria for their indication. Boosting effects on vitamin-dependent signaling pathways could be of interest for patients outside this category. To implement this approach in the near future, it is important to better understand the benefits of these vitamins at the molecular/cellular level by increasing the number of studies in animal models of HF and then conducting clinical trials in HF patients rigorously selected according to criteria established on the basis of the knowledge emerging from those preclinical studies. The integration of $B$ vitamins in the therapeutic arsenal of HF should therefore be considered seriously; these vitamins likely have a strong therapeutic potential that will only be fully exploited when their use is based on better knowledge.

Author Contributions: Writing and editing, J.P., S.E.B., R.V.-C. and M.M.; conceptualization and supervision, J.P. and M.M. All authors have read and agreed to the published version of the manuscript.

Funding: This work was funded by Université Paris Saclay and Institut National de la Santé et de la Recherche Médicale (INSERM). Our laboratory is a member of the Laboratory of Excellence LERMIT and is supported by European Research Area Network on Cardiovascular Diseases (to J.P., \#ANR-19-ECVD-0007-01) and Agence Nationale de la Recherche (to M.M., \#ANR-17-CE17-0015-01).

Institutional Review Board Statement: Not applicable.

Informed Consent Statement: Not applicable.

Data Availability Statement: Not applicable.

Acknowledgments: We thank Anne Garnier, Rodolphe Fischmeister, and Ana-Maria Gomez for continuous support and Fouad Zouein for the careful reading of the manuscript.

Conflicts of Interest: The authors declare no conflict of interest.

\section{References}

1. Groenewegen, A.; Rutten, F.H.; Mosterd, A.; Hoes, A.W. Epidemiology of heart failure. Eur. J. Heart Fail. 2020, 22, 1342-1356 [CrossRef] [PubMed]

2. Jones, N.R.; Roalfe, A.K.; Adoki, I.; Hobbs, F.D.R.; Taylor, C.J. Survival of patients with chronic heart failure in the community: A systematic review and meta-analysis. Eur. J. Heart Fail. 2019, 21, 1306-1325. [CrossRef] [PubMed]

3. Ventura-Clapier, R.; Garnier, A.; Veksler, V.; Joubert, F. Bioenergetics of the failing heart. Biochim. Biophys. Acta 2011, 1813, 1360-1372. [CrossRef] [PubMed]

4. Beer, M.; Seyfarth, T.; Sandstede, J.; Landschutz, W.; Lipke, C.; Kostler, H.; von Kienlin, M.; Harre, K.; Hahn, D.; Neubauer, S. Absolute concentrations of high-energy phosphate metabolites in normal, hypertrophied, and failing human myocardium measured noninvasively with (31)P-SLOOP magnetic resonance spectroscopy. J. Am. Coll. Cardiol. 2002, 40, 1267-1274. [CrossRef]

5. Shen, W.; Asai, K.; Uechi, M.; Mathier, M.A.; Shannon, R.P.; Vatner, S.F.; Ingwall, J.S. Progressive loss of myocardial ATP due to a loss of total purines during the development of heart failure in dogs: A compensatory role for the parallel loss of creatine. Circulation 1999, 100, 2113-2118. [CrossRef]

6. Liao, R.; Nascimben, L.; Friedrich, J.; Gwathmey, J.K.; Ingwall, J.S. Decreased energy reserve in an animal model of dilated cardiomyopathy. Relationship to contractile performance. Circ. Res. 1996, 78, 893-902. [CrossRef] 
7. De Jong, K.A.; Lopaschuk, G.D. Complex Energy Metabolic Changes in Heart Failure with Preserved Ejection Fraction and Heart Failure with Reduced Ejection Fraction. Can. J. Cardiol. 2017, 33, 860-871. [CrossRef]

8. Heggermont, W.A.; Papageorgiou, A.P.; Heymans, S.; van Bilsen, M. Metabolic support for the heart: Complementary therapy for heart failure? Eur. J. Heart Fail. 2016, 18, 1420-1429. [CrossRef]

9. Lopaschuk, G.D.; Karwi, Q.G.; Tian, R.; Wende, A.R.; Abel, E.D. Cardiac Energy Metabolism in Heart Failure. Circ. Res. 2021, 128, 1487-1513. [CrossRef]

10. Lykstad, J.; Sharma, S. Biochemistry, Water Soluble Vitamins. In StatPearls; StatPearls Publishing LLC: Treasure Island, FL, USA, 2021.

11. Nishimoto, A.; Usery, J.; Winton, J.C.; Twilla, J. High-dose Parenteral Thiamine in Treatment of Wernicke's Encephalopathy: Case Series and Review of the Literature. In Vivo 2017, 31, 121-124. [CrossRef]

12. Boina Abdallah, A.; Ogier de Baulny, H.; Kozyraki, R.; Passemard, S.; Fenneteau, O.; Lebon, S.; Rigal, O.; Mesples, B.; Yacouben, K.; Giraudier, S.; et al. How can cobalamin injections be spaced in long-term therapy for inborn errors of vitamin B(12) absorption? Mol. Genet. Metab. 2012, 107, 66-71. [CrossRef]

13. Georgiopoulos, G.; Chrysohoou, C.; Vogiatzi, G.; Magkas, N.; Bournelis, I.; Bampali, S.; Gruson, D.; Tousoulis, D. Vitamins in Heart Failure: Friend or Enemy? Curr. Pharm. Des. 2017, 23, 3731-3742. [CrossRef]

14. Ahmed, M.; Azizi-Namini, P.; Yan, A.T.; Keith, M. Thiamin deficiency and heart failure: The current knowledge and gaps in literature. Heart Fail. Rev. 2015, 20, 1-11. [CrossRef]

15. Keith, M.; Quach, S.; Ahmed, M.; Azizi-Namini, P.; Al-Hesayen, A.; Azevedo, E.; James, R.; Leong-Poi, H.; Ong, G.; Desjardins, S.; et al. Thiamin supplementation does not improve left ventricular ejection fraction in ambulatory heart failure patients: A randomized controlled trial. Am. J. Clin. Nutr. 2019, 110, 1287-1295. [CrossRef]

16. Goel, A.; Kattoor, A.J.; Mehta, J.L. Thiamin therapy for chronic heart failure: Is there any future for this vitamin? Am. J. Clin. Nutr. 2019, 110, 1270-1271. [CrossRef]

17. Jiang, W.L.; Gu, H.B.; Zhang, Y.F.; Xia, Q.Q.; Qi, J.; Chen, J.C. Vitamin D Supplementation in the Treatment of Chronic Heart Failure: A Meta-analysis of Randomized Controlled Trials. Clin. Cardiol. 2016, 39, 56-61. [CrossRef]

18. Witham, M.D.; Crighton, L.J.; Gillespie, N.D.; Struthers, A.D.; McMurdo, M.E. The effects of vitamin D supplementation on physical function and quality of life in older patients with heart failure: A randomized controlled trial. Circ. Heart Fail. 2010, 3 , 195-201. [CrossRef]

19. Dalbeni, A.; Scaturro, G.; Degan, M.; Minuz, P.; Delva, P. Effects of six months of vitamin D supplementation in patients with heart failure: A randomized double-blind controlled trial. Nutr. Metab. Cardiovasc. Dis. 2014, 24, 861-868. [CrossRef]

20. Majeed Babar, M.Z.; Haider, S.S.; Mustafa, G. Effects of Vitamin D supplementation on physical activity of patients with Heart Failure. Pak. J. Med. Sci. 2016, 32, 1430-1433. [CrossRef]

21. Janssen, J.J.E.; Grefte, S.; Keijer, J.; de Boer, V.C.J. Mito-Nuclear Communication by Mitochondrial Metabolites and Its Regulation by B-Vitamins. Front. Physiol. 2019, 10, 78. [CrossRef]

22. Lee, J.H.; Jarreau, T.; Prasad, A.; Lavie, C.; O'Keefe, J.; Ventura, H. Nutritional assessment in heart failure patients. Congest. Heart Fail. 2011, 17, 199-203. [CrossRef]

23. Azizi-Namini, P.; Ahmed, M.; Yan, A.T.; Keith, M. The role of B vitamins in the management of heart failure. Nutr. Clin. Pract. 2012, 27, 363-374. [CrossRef]

24. Neubauer, S. The failing heart-an engine out of fuel. N. Engl. J. Med. 2007, 356, 1140-1151. [CrossRef]

25. Bertero, E.; Maack, C. Metabolic remodelling in heart failure. Nat. Rev. Cardiol. 2018, 15, 457-470. [CrossRef] [PubMed]

26. Geraets, I.M.E.; Glatz, J.F.C.; Luiken, J.; Nabben, M. Pivotal role of membrane substrate transporters on the metabolic alterations in the pressure-overloaded heart. Cardiovasc. Res. 2019, 115, 1000-1012. [CrossRef] [PubMed]

27. Alghamdi, F.; Alshuweishi, Y.; Salt, I.P. Regulation of nutrient uptake by AMP-activated protein kinase. Cell. Signal. 2020, 76, 109807. [CrossRef] [PubMed]

28. Birkenfeld, A.L.; Jordan, J.; Dworak, M.; Merkel, T.; Burnstock, G. Myocardial metabolism in heart failure: Purinergic signalling and other metabolic concepts. Pharmacol. Ther. 2019, 194, 132-144. [CrossRef]

29. Randle, P.J.; Garland, P.B.; Hales, C.N.; Newsholme, E.A. The glucose fatty-acid cycle. Its role in insulin sensitivity and the metabolic disturbances of diabetes mellitus. Lancet 1963, 1, 785-789. [CrossRef]

30. Mitchell, P. Keilin's respiratory chain concept and its chemiosmotic consequences. Science 1979, 206, 1148-1159. [CrossRef]

31. Jonckheere, A.I.; Smeitink, J.A.; Rodenburg, R.J. Mitochondrial ATP synthase: Architecture, function and pathology. J. Inherit. Metab. Dis. 2012, 35, 211-225. [CrossRef]

32. Chance, B.; Williams, G.R. The respiratory chain and oxidative phosphorylation. Adv. Enzymol. Relat. Subj. Biochem. 1956, 17, 65-134.

33. Brown, G.C. Control of respiration and ATP synthesis in mammalian mitochondria and cells. Biochem. J. 1992, 284 Pt 1, 1-13. [CrossRef]

34. Balaban, R.S. Cardiac energy metabolism homeostasis: Role of cytosolic calcium. J. Mol. Cell. Cardiol. 2002, 34, 1259-1271. [CrossRef]

35. Hansford, R.G. Relation between mitochondrial calcium transport and control of energy metabolism. Rev. Physiol. Biochem. Pharmacol 1985, 102, 1-72. 
36. Territo, P.R.; Mootha, V.K.; French, S.A.; Balaban, R.S. $\mathrm{Ca}^{2+}$ activation of heart mitochondrial oxidative phosphorylation: Role of the F(0)/F(1)-ATPase. Am. J. Physiol. Cell Physiol. 2000, 278, C423-C435. [CrossRef]

37. Van der Vusse, G.J.; van Bilsen, M.; Glatz, J.F. Cardiac fatty acid uptake and transport in health and disease. Cardiovasc. Res. 2000, 45, 279-293. [CrossRef]

38. Calvani, M.; Reda, E.; Arrigoni-Martelli, E. Regulation by carnitine of myocardial fatty acid and carbohydrate metabolism under normal and pathological conditions. Basic Res. Cardiol. 2000, 95, 75-83. [CrossRef]

39. Eaton, S. Control of mitochondrial beta-oxidation flux. Prog. Lipid Res. 2002, 41, 197-239. [CrossRef]

40. Sheeran, F.L.; Angerosa, J.; Liaw, N.Y.; Cheung, M.M.; Pepe, S. Adaptations in Protein Expression and Regulated Activity of Pyruvate Dehydrogenase Multienzyme Complex in Human Systolic Heart Failure. Oxidative Med. Cell. Longev. 2019, $2019,4532592$. [CrossRef]

41. Bonen, A.; Heynen, M.; Hatta, H. Distribution of monocarboxylate transporters MCT1-MCT8 in rat tissues and human skeletal muscle. Appl. Physiol. Nutr. Metab. 2006, 31, 31-39. [CrossRef]

42. Abdul Kadir, A.; Clarke, K.; Evans, R.D. Cardiac ketone body metabolism. Biochim. Biophys. Acta Mol. Basis Dis. 2020, $1866,165739$. [CrossRef] [PubMed]

43. Forsey, R.G.; Reid, K.; Brosnan, J.T. Competition between fatty acids and carbohydrate or ketone bodies as metabolic fuels for the isolated perfused heart. Can. J. Physiol. Pharmacol. 1987, 65, 401-406. [CrossRef] [PubMed]

44. Kerbey, A.L.; Randle, P.J.; Cooper, R.H.; Whitehouse, S.; Pask, H.T.; Denton, R.M. Regulation of pyruvate dehydrogenase in rat heart. Mechanism of regulation of proportions of dephosphorylated and phosphorylated enzyme by oxidation of fatty acids and ketone bodies and of effects of diabetes: Role of coenzyme A, acetyl-coenzyme A and reduced and oxidized nicotinamide-adenine dinucleotide. Biochem. J. 1976, 154, 327-348. [CrossRef] [PubMed]

45. Verrey, F. System L: Heteromeric exchangers of large, neutral amino acids involved in directional transport. Pflug. Arch. Eur. J. Physiol. 2003, 445, 529-533. [CrossRef]

46. Nicklin, P.; Bergman, P.; Zhang, B.; Triantafellow, E.; Wang, H.; Nyfeler, B.; Yang, H.; Hild, M.; Kung, C.; Wilson, C.; et al. Bidirectional transport of amino acids regulates mTOR and autophagy. Cell 2009, 136, 521-534. [CrossRef]

47. Neinast, M.; Murashige, D.; Arany, Z. Branched Chain Amino Acids. Annu. Rev. Physiol. 2019, 81, 139-164. [CrossRef]

48. Lu, G.; Sun, H.; She, P.; Youn, J.Y.; Warburton, S.; Ping, P.; Vondriska, T.M.; Cai, H.; Lynch, C.J.; Wang, Y. Protein phosphatase 2Cm is a critical regulator of branched-chain amino acid catabolism in mice and cultured cells. J. Clin. Investig. 2009, 119, 1678-1687. [CrossRef]

49. Lu, G.; Ren, S.; Korge, P.; Choi, J.; Dong, Y.; Weiss, J.; Koehler, C.; Chen, J.N.; Wang, Y. A novel mitochondrial matrix serine/threonine protein phosphatase regulates the mitochondria permeability transition pore and is essential for cellular survival and development. Genes Dev. 2007, 21, 784-796. [CrossRef]

50. Funk, C. On the chemical nature of the substance which cures polyneuritis in birds induced by a diet of polished rice. J. Physiol. 1911, 43, 395-400. [CrossRef]

51. Liu, X.; Bisswanger, H. Interaction of thiamin diphosphate with phosphorylated and dephosphorylated mammalian pyruvate dehydrogenase complex. Biol. Chem. 2005, 386, 11-18. [CrossRef]

52. Shi, Q.; Karuppagounder, S.S.; Xu, H.; Pechman, D.; Chen, H.; Gibson, G.E. Responses of the mitochondrial alpha-ketoglutarate dehydrogenase complex to thiamine deficiency may contribute to regional selective vulnerability. Neurochem. Int. 2007, 50, 921-931. [CrossRef]

53. Li, J.; Wynn, R.M.; Machius, M.; Chuang, J.L.; Karthikeyan, S.; Tomchick, D.R.; Chuang, D.T. Cross-talk between thiamin diphosphate binding and phosphorylation loop conformation in human branched-chain alpha-keto acid decarboxylase/dehydrogenase. J. Biol. Chem. 2004, 279, 32968-32978. [CrossRef]

54. Bettendorff, L.; Wins, P.; Lesourd, M. Subcellular localization and compartmentation of thiamine derivatives in rat brain. Biochim. Biophys. Acta 1994, 1222, 1-6. [CrossRef]

55. Mkrtchyan, G.; Aleshin, V.; Parkhomenko, Y.; Kaehne, T.; Di Salvo, M.L.; Parroni, A.; Contestabile, R.; Vovk, A.; Bettendorff, L.; Bunik, V. Molecular mechanisms of the non-coenzyme action of thiamin in brain: Biochemical, structural and pathway analysis. Sci. Rep. 2015, 5, 12583. [CrossRef]

56. Subramanya, S.B.; Subramanian, V.S.; Said, H.M. Chronic alcohol consumption and intestinal thiamin absorption: Effects on physiological and molecular parameters of the uptake process. Am. J. Physiol. Gastrointest. Liver Physiol. 2010, 299, G23-G31. [CrossRef]

57. Depeint, F.; Bruce, W.R.; Shangari, N.; Mehta, R.; O'Brien, P.J. Mitochondrial function and toxicity: Role of the B vitamin family on mitochondrial energy metabolism. Chem. Biol. Interact. 2006, 163, 94-112. [CrossRef]

58. Barile, M.; Passarella, S.; Quagliariello, E. Thiamine pyrophosphate uptake into isolated rat liver mitochondria. Arch. Biochem. Biophys. 1990, 280, 352-357. [CrossRef]

59. Kim, J.J.; Miura, R. Acyl-CoA dehydrogenases and acyl-CoA oxidases. Structural basis for mechanistic similarities and differences. Eur. J. Biochem. 2004, 271, 483-493. [CrossRef]

60. Henriques, B.J.; Katrine Jentoft Olsen, R.; Gomes, C.M.; Bross, P. Electron transfer flavoprotein and its role in mitochondrial energy metabolism in health and disease. Gene 2021, 776, 145407. [CrossRef]

61. Kim, H.J.; Winge, D.R. Emerging concepts in the flavinylation of succinate dehydrogenase. Biochim. Biophys. Acta 2013, 1827, 627-636. [CrossRef] 
62. Schulz, G.E.; Schirmer, R.H.; Pai, E.F. FAD-binding site of glutathione reductase. J. Mol. Biol. 1982, 160, 287-308. [CrossRef]

63. Powers, H.J. Riboflavin (vitamin B-2) and health. Am. J. Clin. Nutr. 2003, 77, 1352-1360. [CrossRef]

64. Jaeger, B.; Bosch, A.M. Clinical presentation and outcome of riboflavin transporter deficiency: Mini review after five years of experience. J. Inherit. Metab. Dis. 2016, 39, 559-564. [CrossRef]

65. Goldberger, J. The etiology of Pellagra. Public Health Rep. 1914, 29, 1683-1686. [CrossRef]

66. Elvehjem, C.; Madden, R.; Strong, F.; Woolley, D. Relation of nicotinic acid and nicotinic acid amide to canine black tongue. J. Am. Chem. Soc. 1937, 59, 1767. [CrossRef]

67. Bogan, K.L.; Brenner, C. Nicotinic acid, nicotinamide, and nicotinamide riboside: A molecular evaluation of NAD ${ }^{+}$precursor vitamins in human nutrition. Annu. Rev. Nutr. 2008, 28, 115-130. [CrossRef]

68. Yoshino, J.; Baur, J.A.; Imai, S.I. NAD ${ }^{+}$Intermediates: The Biology and Therapeutic Potential of NMN and NR. Cell Metab. 2018, 27, 513-528. [CrossRef]

69. Grozio, A.; Mills, K.F.; Yoshino, J.; Bruzzone, S.; Sociali, G.; Tokizane, K.; Lei, H.C.; Cunningham, R.; Sasaki, Y.; Migaud, M.E.; et al. Slc12a8 is a nicotinamide mononucleotide transporter. Nat. Metab. 2019, 1, 47-57. [CrossRef]

70. Schmidt, M.S.; Brenner, C. Absence of evidence that Slc12a8 encodes a nicotinamide mononucleotide transporter. Nat. Metab. 2019, 1, 660-661. [CrossRef]

71. Zhang, R. MNADK, a Long-Awaited Human Mitochondrion-Localized NAD Kinase. J. Cell. Physiol. 2015, 230, 1697-1701. [CrossRef]

72. Lee, M.H.; Malloy, C.R.; Corbin, I.R.; Li, J.; Jin, E.S. Assessing the pentose phosphate pathway using [2, 3-(13) C2 ]glucose. NMR Biomed. 2019, 32, e4096. [CrossRef] [PubMed]

73. Ronchi, J.A.; Francisco, A.; Passos, L.A.; Figueira, T.R.; Castilho, R.F. The Contribution of Nicotinamide Nucleotide Transhydrogenase to Peroxide Detoxification Is Dependent on the Respiratory State and Counterbalanced by Other Sources of NADPH in Liver Mitochondria. J. Biol. Chem. 2016, 291, 20173-20187. [CrossRef] [PubMed]

74. Nickel, A.G.; von Hardenberg, A.; Hohl, M.; Loffler, J.R.; Kohlhaas, M.; Becker, J.; Reil, J.C.; Kazakov, A.; Bonnekoh, J.; Stadelmaier, M.; et al. Reversal of Mitochondrial Transhydrogenase Causes Oxidative Stress in Heart Failure. Cell Metab. 2015, 22, 472-484. [CrossRef] [PubMed]

75. Mericskay, M. Nicotinamide adenine dinucleotide homeostasis and signalling in heart disease: Pathophysiological implications and therapeutic potential. Arch. Cardiovasc. Dis. 2016, 109, 207-215. [CrossRef]

76. Matsushima, S.; Sadoshima, J. The role of sirtuins in cardiac disease. Am. J. Physiol. Heart Circ. Physiol. 2015, 309, H1375-H1389. [CrossRef]

77. Sanz, M.N.; Grimbert, L.; Moulin, M.; Gressette, M.; Rucker-Martin, C.; Lemaire, C.; Mericskay, M.; Veksler, V.; Ventura-Clapier, R.; Garnier, A.; et al. Inducible Cardiac-Specific Deletion of Sirt1 in Male Mice Reveals Progressive Cardiac Dysfunction and Sensitization of the Heart to Pressure Overload. Int. J. Mol. Sci. 2019, 20, 505. [CrossRef]

78. Rodgers, J.T.; Lerin, C.; Haas, W.; Gygi, S.P.; Spiegelman, B.M.; Puigserver, P. Nutrient control of glucose homeostasis through a complex of PGC-1alpha and SIRT1. Nature 2005, 434, 113-118. [CrossRef]

79. Baum, C.L.; Selhub, J.; Rosenberg, I.H. The hydrolysis of nicotinamide adenine nucleotide by brush border membranes of rat intestine. Biochem. J. 1982, 204, 203-207. [CrossRef]

80. Gross, C.J.; Henderson, L.M. Digestion and absorption of NAD by the small intestine of the rat. J. Nutr. 1983, 113, 412-420 [CrossRef]

81. Shats, I.; Williams, J.G.; Liu, J.; Makarov, M.V.; Wu, X.; Lih, F.B.; Deterding, L.J.; Lim, C.; Xu, X.; Randall, T.A.; et al. Bacteria Boost Mammalian Host NAD Metabolism by Engaging the Deamidated Biosynthesis Pathway. Cell Metab. 2020, 31, 564-579.e567. [CrossRef]

82. Kropotov, A.; Kulikova, V.; Nerinovski, K.; Yakimov, A.; Svetlova, M.; Solovjeva, L.; Sudnitsyna, J.; Migaud, M.E.; Khodorkovskiy, M.; Ziegler, M.; et al. Equilibrative Nucleoside Transporters Mediate the Import of Nicotinamide Riboside and Nicotinic Acid Riboside into Human Cells. Int. J. Mol. Sci. 2021, 22, 1391. [CrossRef]

83. Vaur, P.; Brugg, B.; Mericskay, M.; Li, Z.; Schmidt, M.S.; Vivien, D.; Orset, C.; Jacotot, E.; Brenner, C.; Duplus, E. Nicotinamide riboside, a form of vitamin B3, protects against excitotoxicity-induced axonal degeneration. FASEB J. Off. Publ. Fed. Am. Soc. Exp. Biol. 2017, 31, 5440-5452. [CrossRef]

84. Mathialagan, S.; Bi, Y.A.; Costales, C.; Kalgutkar, A.S.; Rodrigues, A.D.; Varma, M.V.S. Nicotinic acid transport into human liver involves organic anion transporter 2 (SLC22A7). Biochem. Pharmacol. 2020, 174, 113829. [CrossRef]

85. Fletcher, R.S.; Ratajczak, J.; Doig, C.L.; Oakey, L.A.; Callingham, R.; Da Silva Xavier, G.; Garten, A.; Elhassan, Y.S.; Redpath, P.; Migaud, M.E.; et al. Nicotinamide riboside kinases display redundancy in mediating nicotinamide mononucleotide and nicotinamide riboside metabolism in skeletal muscle cells. Mol. Metab. 2017, 6, 819-832. [CrossRef]

86. Kulikova, V.; Shabalin, K.; Nerinovski, K.; Yakimov, A.; Svetlova, M.; Solovjeva, L.; Kropotov, A.; Khodorkovskiy, M.; Migaud, M.E.; Ziegler, M.; et al. Degradation of Extracellular NAD ${ }^{+}$Intermediates in Cultures of Human HEK293 Cells. Metabolites 2019, 9, 293. [CrossRef]

87. Martinez, D.L.; Tsuchiya, Y.; Gout, I. Coenzyme A biosynthetic machinery in mammalian cells. Biochem. Soc. Trans. 2014, 42, 1112-1117. [CrossRef]

88. Prasad, P.D.; Wang, H.; Huang, W.; Fei, Y.J.; Leibach, F.H.; Devoe, L.D.; Ganapathy, V. Molecular and functional characterization of the intestinal $\mathrm{Na}^{+}$-dependent multivitamin transporter. Arch. Biochem. Biophys. 1999, 366, 95-106. [CrossRef] 
89. Naquet, P.; Kerr, E.W.; Vickers, S.D.; Leonardi, R. Regulation of coenzyme A levels by degradation: The 'Ins and Outs'. Prog. Lipid. Res. 2020, 78, 101028. [CrossRef]

90. Patra, S.; Barondeau, D.P. Mechanism of activation of the human cysteine desulfurase complex by frataxin. Proc. Natl. Acad. Sci. USA 2019, 116, 19421-19430. [CrossRef]

91. Le Breton, N.; Wright, J.J.; Jones, A.J.Y.; Salvadori, E.; Bridges, H.R.; Hirst, J.; Roessler, M.M. Using Hyperfine Electron Paramagnetic Resonance Spectroscopy to Define the Proton-Coupled Electron Transfer Reaction at Fe-S Cluster N2 in Respiratory Complex I. J. Am. Chem. Soc. 2017, 139, 16319-16326. [CrossRef]

92. Markevich, N.I.; Markevich, L.N.; Hoek, J.B. Computational Modeling Analysis of Generation of Reactive Oxygen Species by Mitochondrial Assembled and Disintegrated Complex II. Front. Physiol. 2020, 11, 557721. [CrossRef] [PubMed]

93. Depeint, F.; Bruce, W.R.; Shangari, N.; Mehta, R.; O’Brien, P.J. Mitochondrial function and toxicity: Role of B vitamins on the one-carbon transfer pathways. Chem. Biol. Interact. 2006, 163, 113-132. [CrossRef] [PubMed]

94. Oxenkrug, G. Insulin resistance and dysregulation of tryptophan-kynurenine and kynurenine-nicotinamide adenine dinucleotide metabolic pathways. Mol. Neurobiol. 2013, 48, 294-301. [CrossRef] [PubMed]

95. Liu, X.; Szebenyi, D.M.; Anguera, M.C.; Thiel, D.J.; Stover, P.J. Lack of catalytic activity of a murine mRNA cytoplasmic serine hydroxymethyltransferase splice variant: Evidence against alternative splicing as a regulatory mechanism. Biochemistry 2001, 40, 4932-4939. [CrossRef]

96. Zhu, W.; Lin, A.; Banerjee, R. Kinetic properties of polymorphic variants and pathogenic mutants in human cystathionine gamma-lyase. Biochemistry 2008, 47, 6226-6232. [CrossRef]

97. Lu, S.C. Glutathione synthesis. Biochim. Biophys. Acta 2013, 1830, 3143-3153. [CrossRef]

98. Stojanovski, B.M.; Hunter, G.A.; Na, I.; Uversky, V.N.; Jiang, R.H.Y.; Ferreira, G.C. 5-Aminolevulinate synthase catalysis: The catcher in heme biosynthesis. Mol. Genet. Metab. 2019, 128, 178-189. [CrossRef]

99. Albersen, M.; Bosma, M.; Knoers, N.V.; de Ruiter, B.H.; Diekman, E.F.; de Ruijter, J.; Visser, W.F.; de Koning, T.J.; Verhoeven-Duif, N.M. The intestine plays a substantial role in human vitamin B6 metabolism: A Caco-2 cell model. PLoS ONE 2013, 8, e54113. [CrossRef]

100. Mehansho, H.; Hamm, M.W.; Henderson, L.M. Transport and metabolism of pyridoxal and pyridoxal phosphate in the small intestine of the rat. J. Nutr. 1979, 109, 1542-1551. [CrossRef]

101. Said, H.M.; Ortiz, A.; Ma, T.Y. A carrier-mediated mechanism for pyridoxine uptake by human intestinal epithelial Caco-2 cells: Regulation by a PKA-mediated pathway. Am. J. Physiol. Cell Physiol. 2003, 285, C1219-C1225. [CrossRef]

102. Said, Z.M.; Subramanian, V.S.; Vaziri, N.D.; Said, H.M. Pyridoxine uptake by colonocytes: A specific and regulated carriermediated process. Am. J. Physiol. Cell Physiol. 2008, 294, C1192-C1197. [CrossRef]

103. Tong, L. Striking Diversity in Holoenzyme Architecture and Extensive Conformational Variability in Biotin-Dependent Carboxylases. Adv. Protein Chem. Struct. Biol. 2017, 109, 161-194. [CrossRef]

104. Kusunoki, J.; Kanatani, A.; Moller, D.E. Modulation of fatty acid metabolism as a potential approach to the treatment of obesity and the metabolic syndrome. Endocrine 2006, 29, 91-100. [CrossRef]

105. Abo Alrob, O.; Lopaschuk, G.D. Role of CoA and acetyl-CoA in regulating cardiac fatty acid and glucose oxidation. Biochem. Soc. Trans. 2014, 42, 1043-1051. [CrossRef]

106. Armstrong, A.J.; Collado, M.S.; Henke, B.R.; Olson, M.W.; Hoang, S.A.; Hamilton, C.A.; Pourtaheri, T.D.; Chapman, K.A.; Summar, M.M.; Johns, B.A.; et al. A novel small molecule approach for the treatment of propionic and methylmalonic acidemias. Mol. Genet. Metab. 2021, 133, 71-82. [CrossRef]

107. Cozzolino, C.; Villani, G.R.; Frisso, G.; Scolamiero, E.; Albano, L.; Gallo, G.; Romanelli, R.; Ruoppolo, M. Biochemical and molecular characterization of 3-Methylcrotonylglycinuria in an Italian asymptomatic girl. Genet. Mol. Biol. 2018, 41, 379-385. [CrossRef]

108. Koury, M.J.; Ponka, P. New insights into erythropoiesis: The roles of folate, vitamin B12, and iron. Annu. Rev. Nutr. 2004, 24, 105-131. [CrossRef]

109. Choi, S.W.; Mason, J.B. Folate status: Effects on pathways of colorectal carcinogenesis. J. Nutr. 2002, 132, 2413S-2418S. [CrossRef]

110. Ducker, G.S.; Rabinowitz, J.D. One-Carbon Metabolism in Health and Disease. Cell Metab. 2017, 25, 27-42. [CrossRef]

111. Vandesompele, J.; De Preter, K.; Pattyn, F.; Poppe, B.; Van Roy, N.; De Paepe, A.; Speleman, F. Accurate normalization of real-time quantitative RT-PCR data by geometric averaging of multiple internal control genes. Genome Biol. 2002, 3, research0034.1. [CrossRef]

112. Gregory, J.F., 3rd; Cuskelly, G.J.; Shane, B.; Toth, J.P.; Baumgartner, T.G.; Stacpoole, P.W. Primed, constant infusion with [2H3]serine allows in vivo kinetic measurement of serine turnover, homocysteine remethylation, and transsulfuration processes in human one-carbon metabolism. Am. J. Clin. Nutr. 2000, 72, 1535-1541. [CrossRef]

113. Joseph, J.; Loscalzo, J. Methoxistasis: Integrating the roles of homocysteine and folic acid in cardiovascular pathobiology. Nutrients 2013, 5, 3235-3256. [CrossRef]

114. Teyssier, C.; Ma, H.; Emter, R.; Kralli, A.; Stallcup, M.R. Activation of nuclear receptor coactivator PGC-1alpha by arginine methylation. Genes Dev. 2005, 19, 1466-1473. [CrossRef]

115. Ghemrawi, R.; Pooya, S.; Lorentz, S.; Gauchotte, G.; Arnold, C.; Gueant, J.L.; Battaglia-Hsu, S.F. Decreased vitamin B12 availability induces ER stress through impaired SIRT1-deacetylation of HSF1. Cell Death Dis. 2013, 4, e553. [CrossRef] [PubMed] 
116. Joshi, R.; Adhikari, S.; Patro, B.S.; Chattopadhyay, S.; Mukherjee, T. Free radical scavenging behavior of folic acid: Evidence for possible antioxidant activity. Free Radic. Biol. Med. 2001, 30, 1390-1399. [CrossRef]

117. Tucker, E.J.; Hershman, S.G.; Kohrer, C.; Belcher-Timme, C.A.; Patel, J.; Goldberger, O.A.; Christodoulou, J.; Silberstein, J.M.; McKenzie, M.; Ryan, M.T.; et al. Mutations in MTFMT underlie a human disorder of formylation causing impaired mitochondrial translation. Cell Metab. 2011, 14, 428-434. [CrossRef] [PubMed]

118. Wright, A.J.; Dainty, J.R.; Finglas, P.M. Folic acid metabolism in human subjects revisited: Potential implications for proposed mandatory folic acid fortification in the UK. Br. J. Nutr. 2007, 98, 667-675. [CrossRef] [PubMed]

119. Zhan, H.Q.; Najmi, M.; Lin, K.; Aluri, S.; Fiser, A.; Goldman, I.D.; Zhao, R. A proton-coupled folate transporter mutation causing hereditary folate malabsorption locks the protein in an inward-open conformation. J. Biol. Chem. 2020, 295, 15650-15661. [CrossRef]

120. Krautler, B. Biochemistry of B12-cofactors in human metabolism. Subcell. Biochem. 2012, 56, 323-346. [CrossRef]

121. Mascarenhas, R.; Ruetz, M.; McDevitt, L.; Koutmos, M.; Banerjee, R. Mobile loop dynamics in adenosyltransferase control binding and reactivity of coenzyme B12. Proc. Natl. Acad. Sci. USA 2020, 117, 30412-30422. [CrossRef]

122. Quadros, E.V. Advances in the understanding of cobalamin assimilation and metabolism. Br. J. Haematol. 2010, 148, 195-204. [CrossRef]

123. Kristiansen, M.; Kozyraki, R.; Jacobsen, C.; Nexo, E.; Verroust, P.J.; Moestrup, S.K. Molecular dissection of the intrinsic factorvitamin B12 receptor, cubilin, discloses regions important for membrane association and ligand binding. J. Biol. Chem. 1999, 274, 20540-20544. [CrossRef]

124. Doenst, T.; Nguyen, T.D.; Abel, E.D. Cardiac metabolism in heart failure: Implications beyond ATP production. Circ. Res. 2013, 113, 709-724. [CrossRef]

125. Kolwicz, S.C., Jr.; Purohit, S.; Tian, R. Cardiac metabolism and its interactions with contraction, growth, and survival of cardiomyocytes. Circ. Res. 2013, 113, 603-616. [CrossRef]

126. Ventura-Clapier, R.; Garnier, A.; Veksler, V. Energy metabolism in heart failure. J. Physiol. 2004, 555, 1-13. [CrossRef]

127. Chandler, M.P.; Kerner, J.; Huang, H.; Vazquez, E.; Reszko, A.; Martini, W.Z.; Hoppel, C.L.; Imai, M.; Rastogi, S.; Sabbah, H.N.; et al. Moderate severity heart failure does not involve a downregulation of myocardial fatty acid oxidation. Am. J. Physiol. Heart Circ. Physiol. 2004, 287, H1538-H1543. [CrossRef]

128. Doenst, T.; Pytel, G.; Schrepper, A.; Amorim, P.; Farber, G.; Shingu, Y.; Mohr, F.W.; Schwarzer, M. Decreased rates of substrate oxidation ex vivo predict the onset of heart failure and contractile dysfunction in rats with pressure overload. Cardiovasc. Res. 2010, 86, 461-470. [CrossRef]

129. Stanley, W.C.; Recchia, F.A.; Lopaschuk, G.D. Myocardial substrate metabolism in the normal and failing heart. Physiol. Rev. 2005, 85, 1093-1129. [CrossRef]

130. Sack, M.N.; Rader, T.A.; Park, S.; Bastin, J.; McCune, S.A.; Kelly, D.P. Fatty acid oxidation enzyme gene expression is downregulated in the failing heart. Circulation 1996, 94, 2837-2842. [CrossRef]

131. Karbowska, J.; Kochan, Z.; Smolenski, R.T. Peroxisome proliferator-activated receptor alpha is downregulated in the failing human heart. Cell Mol. Biol. Lett. 2003, 8, 49-53.

132. Garnier, A.; Fortin, D.; Delomenie, C.; Momken, I.; Veksler, V.; Ventura-Clapier, R. Depressed mitochondrial transcription factors and oxidative capacity in rat failing cardiac and skeletal muscles. J. Physiol. 2003, 551, 491-501. [CrossRef]

133. Pawlak, M.; Lefebvre, P.; Staels, B. Molecular mechanism of PPARalpha action and its impact on lipid metabolism, inflammation and fibrosis in non-alcoholic fatty liver disease. J. Hepatol. 2015, 62, 720-733. [CrossRef]

134. Razeghi, P.; Young, M.E.; Alcorn, J.L.; Moravec, C.S.; Frazier, O.H.; Taegtmeyer, H. Metabolic gene expression in fetal and failing human heart. Circulation 2001, 104, 2923-2931. [CrossRef]

135. Piquereau, J.; Ventura-Clapier, R. Maturation of Cardiac Energy Metabolism During Perinatal Development. Front. Physiol. 2018, 9, 959. [CrossRef]

136. Akki, A.; Smith, K.; Seymour, A.M. Compensated cardiac hypertrophy is characterised by a decline in palmitate oxidation. Mol. Cell. Biochem. 2008, 311, 215-224. [CrossRef]

137. Degens, H.; de Brouwer, K.F.; Gilde, A.J.; Lindhout, M.; Willemsen, P.H.; Janssen, B.J.; van der Vusse, G.J.; van Bilsen, M. Cardiac fatty acid metabolism is preserved in the compensated hypertrophic rat heart. Basic Res. Cardiol. 2006, 101, 17-26. [CrossRef]

138. Biesemann, N.; Mendler, L.; Wietelmann, A.; Hermann, S.; Schafers, M.; Kruger, M.; Boettger, T.; Borchardt, T.; Braun, T. Myostatin regulates energy homeostasis in the heart and prevents heart failure. Circ. Res. 2014, 115, 296-310. [CrossRef]

139. Taegtmeyer, H. Metabolism-The lost child of cardiology. J. Am. Coll. Cardiol. 2000, 36, 1386-1388. [CrossRef]

140. Leong, H.S.; Brownsey, R.W.; Kulpa, J.E.; Allard, M.F. Glycolysis and pyruvate oxidation in cardiac hypertrophy-Why so unbalanced? Comp. Biochem. Physiol. A Mol. Integr. Physiol. 2003, 135, 499-513. [CrossRef]

141. Zhou, B.; Tian, R. Mitochondrial dysfunction in pathophysiology of heart failure. J. Clin. Investig. 2018, 128, 3716-3726. [CrossRef]

142. De Sousa, E.; Veksler, V.; Minajeva, A.; Kaasik, A.; Mateo, P.; Mayoux, E.; Hoerter, J.; Bigard, X.; Serrurier, B.; Ventura-Clapier, R. Subcellular creatine kinase alterations. Implications in heart failure. Circ. Res. 1999, 85, 68-76. [CrossRef] [PubMed]

143. Ingwall, J.S.; Weiss, R.G. Is the failing heart energy starved? On using chemical energy to support cardiac function. Circ. Res. 2004, 95, 135-145. [CrossRef] [PubMed]

144. Ventura-Clapier, R.; Kuznetsov, A.; Veksler, V.; Boehm, E.; Anflous, K. Functional coupling of creatine kinases in muscles: Species and tissue specificity. Mol. Cell Biochem. 1998, 184, 231-247. [CrossRef] [PubMed] 
145. Bayeva, M.; Ardehali, H. Mitochondrial dysfunction and oxidative damage to sarcomeric proteins. Curr. Hypertens. Rep. 2010, 12, 426-432. [CrossRef]

146. Gorelik, O.; Almoznino-Sarafian, D.; Feder, I.; Wachsman, O.; Alon, I.; Litvinjuk, V.; Roshovsky, M.; Modai, D.; Cohen, N. Dietary intake of various nutrients in older patients with congestive heart failure. Cardiology 2003, 99, 177-181. [CrossRef]

147. Arcand, J.; Floras, V.; Ahmed, M.; Al-Hesayen, A.; Ivanov, J.; Allard, J.P.; Newton, G.E. Nutritional inadequacies in patients with stable heart failure. J. Am. Diet. Assoc. 2009, 109, 1909-1913. [CrossRef]

148. Krim, S.R.; Campbell, P.; Lavie, C.J.; Ventura, H. Micronutrients in chronic heart failure. Curr. Heart Fail. Rep. 2013, 10, 46-53. [CrossRef]

149. Keith, M.E.; Walsh, N.A.; Darling, P.B.; Hanninen, S.A.; Thirugnanam, S.; Leong-Poi, H.; Barr, A.; Sole, M.J. B-vitamin deficiency in hospitalized patients with heart failure. J. Am. Diet. Assoc. 2009, 109, 1406-1410. [CrossRef]

150. Mitu, O.; Cirneala, I.A.; Lupsan, A.I.; Iurciuc, M.; Mitu, I.; Dimitriu, D.C.; Costache, A.D.; Petris, A.O.; Costache, I.I. The Effect of Vitamin Supplementation on Subclinical Atherosclerosis in Patients without Manifest Cardiovascular Diseases: Never-ending Hope or Underestimated Effect? Molecules 2020, 25, 1717. [CrossRef]

151. Jain, A.; Mehta, R.; Al-Ani, M.; Hill, J.A.; Winchester, D.E. Determining the Role of Thiamine Deficiency in Systolic Heart Failure: A Meta-Analysis and Systematic Review. J. Card. Fail. 2015, 21, 1000-1007. [CrossRef]

152. Kattoor, A.J.; Goel, A.; Mehta, J.L. Thiamine Therapy for Heart Failure: A Promise or Fiction? Cardiovasc. Drugs Ther. 2018, 32, 313-317. [CrossRef]

153. Seligmann, H.; Halkin, H.; Rauchfleisch, S.; Kaufmann, N.; Motro, M.; Vered, Z.; Ezra, D. Thiamine deficiency in patients with congestive heart failure receiving long-term furosemide therapy: A pilot study. Am. J. Med. 1991, 91, 151-155. [CrossRef]

154. Zenuk, C.; Healey, J.; Donnelly, J.; Vaillancourt, R.; Almalki, Y.; Smith, S. Thiamine deficiency in congestive heart failure patients receiving long term furosemide therapy. Can. J. Clin. Pharmacol. 2003, 10, 184-188.

155. Katta, N.; Balla, S.; Alpert, M.A. Does Long-Term Furosemide Therapy Cause Thiamine Deficiency in Patients with Heart Failure? A Focused Review. Am. J. Med. 2016, 129, 753.e7-753.e11. [CrossRef]

156. Rieck, J.; Halkin, H.; Almog, S.; Seligman, H.; Lubetsky, A.; Olchovsky, D.; Ezra, D. Urinary loss of thiamine is increased by low doses of furosemide in healthy volunteers. J. Lab. Clin. Med. 1999, 134, 238-243. [CrossRef]

157. Yamada, Y.; Kusakari, Y.; Akaoka, M.; Watanabe, M.; Tanihata, J.; Nishioka, N.; Bochimoto, H.; Akaike, T.; Tachibana, T.; Minamisawa, $\mathrm{S}$. Thiamine treatment preserves cardiac function against ischemia injury via maintaining mitochondrial size and ATP levels. J. Appl. Physiol. 2021, 130, 26-35. [CrossRef]

158. Katare, R.; Caporali, A.; Emanueli, C.; Madeddu, P. Benfotiamine improves functional recovery of the infarcted heart via activation of pro-survival G6PD/Akt signaling pathway and modulation of neurohormonal response. J. Mol. Cell. Cardiol. 2010, 49, 625-638. [CrossRef]

159. Ahmed, L.A.; Hassan, O.F.; Galal, O.; Mansour, D.F.; El-Khatib, A. Beneficial effects of benfotiamine, a NADPH oxidase inhibitor in isoproterenol-induced myocardial infarction in rats. PLOS ONE 2020, 15, e0232413. [CrossRef]

160. Radonjic, T.; Rankovic, M.; Ravic, M.; Zivkovic, V.; Srejovic, I.; Jeremic, J.; Jeremic, N.; Sretenovic, J.; Matic, S.; Jakovljevic, V.; et al. The Effects of Thiamine Hydrochloride on Cardiac Function, Redox Status and Morphometric Alterations in Doxorubicin-Treated Rats. Cardiovasc. Toxicol 2020, 20, 111-120. [CrossRef]

161. Katare, R.G.; Caporali, A.; Oikawa, A.; Meloni, M.; Emanueli, C.; Madeddu, P. Vitamin B1 analog benfotiamine prevents diabetes-induced diastolic dysfunction and heart failure through Akt/Pim-1-mediated survival pathway. Circ. Heart Fail. 2010, 3, 294-305. [CrossRef]

162. Goncalves, A.C.; Moreira, E.J.S.; Portari, G.V. Benfotiamine supplementation prevents oxidative stress in anterior tibialis muscle and heart. J. Integr. Med. 2019, 17, 423-429. [CrossRef]

163. Kohda, Y.; Umeki, M.; Kono, T.; Terasaki, F.; Matsumura, H.; Tanaka, T. Thiamine ameliorates diabetes-induced inhibition of pyruvate dehydrogenase (PDH) in rat heart mitochondria: Investigating the discrepancy between PDH activity and PDH E1alpha phosphorylation in cardiac fibroblasts exposed to high glucose. J. Pharmacol. Sci. 2010, 113, 343-352. [CrossRef]

164. Shimon, I.; Almog, S.; Vered, Z.; Seligmann, H.; Shefi, M.; Peleg, E.; Rosenthal, T.; Motro, M.; Halkin, H.; Ezra, D. Improved left ventricular function after thiamine supplementation in patients with congestive heart failure receiving long-term furosemide therapy. Am. J. Med. 1995, 98, 485-490. [CrossRef]

165. Schoenenberger, A.W.; Schoenenberger-Berzins, R.; der Maur, C.A.; Suter, P.M.; Vergopoulos, A.; Erne, P. Thiamine supplementation in symptomatic chronic heart failure: A randomized, double-blind, placebo-controlled, cross-over pilot study. Clin. Res. Cardiol. 2012, 101, 159-164. [CrossRef] [PubMed]

166. Pfitzenmeyer, P.; Guilland, J.C.; d'Athis, P.; Petit-Marnier, C.; Gaudet, M. Thiamine status of elderly patients with cardiac failure including the effects of supplementation. Int. J. Vitam. Nutr. Res. 1994, 64, 113-118. [PubMed]

167. Mousavi, M.; Namazi, S.; Avadi, M.; Amirahmadi, M.; Salehifar, D. Thiamine Supplementation in Patients with Chronic Heart Failure Receiving Optimum Medical Treatment. J. Cardiol. Curr. Res. 2017, 9, 00316. [CrossRef]

168. Smithline, H.A.; Donnino, M.; Blank, F.S.J.; Barus, R.; Coute, R.A.; Knee, A.B.; Visintainer, P. Supplemental thiamine for the treatment of acute heart failure syndrome: A randomized controlled trial. BMC Complement. Altern. Med. 2019, 19, 96. [CrossRef] [PubMed]

169. Hughes, C.M.; Woodside, J.V.; McGartland, C.; Roberts, M.J.; Nicholls, D.P.; McKeown, P.P. Nutritional intake and oxidative stress in chronic heart failure. Nutr. Metab. Cardiovasc. Dis. 2012, 22, 376-382. [CrossRef] 
170. McKeag, N.A.; McKinley, M.C.; Harbinson, M.T.; McGinty, A.; Neville, C.E.; Woodside, J.V.; McKeown, P.P. Dietary Micronutrient Intake and Micronutrient Status in Patients With Chronic Stable Heart Failure: An Observational Study. J. Cardiovasc. Nurs. 2017, 32, 148-155. [CrossRef]

171. Witte, K.K.; Nikitin, N.P.; Parker, A.C.; von Haehling, S.; Volk, H.D.; Anker, S.D.; Clark, A.L.; Cleland, J.G. The effect of micronutrient supplementation on quality-of-life and left ventricular function in elderly patients with chronic heart failure. Eur. Heart J. 2005, 26, 2238-2244. [CrossRef]

172. Wang, P.; Fan, F.; Li, X.; Sun, X.; Ma, L.; Wu, J.; Shen, C.; Zhu, H.; Dong, Z.; Wang, C.; et al. Riboflavin attenuates myocardial injury via LSD1-mediated crosstalk between phospholipid metabolism and histone methylation in mice with experimental myocardial infarction. J. Mol. Cell. Cardiol. 2018, 115, 115-129. [CrossRef]

173. Lucas, T.G.; Henriques, B.J.; Rodrigues, J.V.; Bross, P.; Gregersen, N.; Gomes, C.M. Cofactors and metabolites as potential stabilizers of mitochondrial acyl-CoA dehydrogenases. Biochim. Biophys. Acta 2011, 1812, 1658-1663. [CrossRef]

174. Ma, Z.; Qin, X.; Zhong, X.; Liao, Y.; Su, Y.; Liu, X.; Liu, P.; Lu, J.; Zhou, S. Flavine adenine dinucleotide inhibits pathological cardiac hypertrophy and fibrosis through activating short chain acyl-CoA dehydrogenase. Biochem. Pharm. 2020, 178, 114100. [CrossRef]

175. Wang, G.; Li, W.; Lu, X.; Zhao, X. Riboflavin alleviates cardiac failure in Type I diabetic cardiomyopathy. Heart Int. 2011,6 , e21. [CrossRef]

176. Karamanlidis, G.; Lee, C.F.; Garcia-Menendez, L.; Kolwicz, S.C., Jr.; Suthammarak, W.; Gong, G.; Sedensky, M.M.; Morgan, P.G.; Wang, W.; Tian, R. Mitochondrial complex I deficiency increases protein acetylation and accelerates heart failure. Cell Metab. 2013, 18, 239-250. [CrossRef]

177. Lee, C.F.; Chavez, J.D.; Garcia-Menendez, L.; Choi, Y.; Roe, N.D.; Chiao, Y.A.; Edgar, J.S.; Goo, Y.A.; Goodlett, D.R.; Bruce, J.E.; et al. Normalization of NAD ${ }^{+}$Redox Balance as a Therapy for Heart Failure. Circulation 2016, 134, 883-894. [CrossRef]

178. Di Lisa, F.; Menabo, R.; Canton, M.; Barile, M.; Bernardi, P. Opening of the mitochondrial permeability transition pore causes depletion of mitochondrial and cytosolic $\mathrm{NAD}^{+}$and is a causative event in the death of myocytes in postischemic reperfusion of the heart. J. Biol. Chem. 2001, 276, 2571-2575. [CrossRef]

179. Diguet, N.; Trammell, S.A.J.; Tannous, C.; Deloux, R.; Piquereau, J.; Mougenot, N.; Gouge, A.; Gressette, M.; Manoury, B.; Blanc, J.; et al. Nicotinamide Riboside Preserves Cardiac Function in a Mouse Model of Dilated Cardiomyopathy. Circulation 2017, 137, 2256-2273. [CrossRef]

180. Vignier, N.; Chatzifrangkeskou, M.; Morales Rodriguez, B.; Mericskay, M.; Mougenot, N.; Wahbi, K.; Bonne, G.; Muchir, A. Rescue of biosynthesis of nicotinamide adenine dinucleotide protects the heart in cardiomyopathy caused by lamin $\mathrm{A} / \mathrm{C}$ gene mutation. Hum. Mol. Genet. 2018, 27, 3870-3880. [CrossRef]

181. Chiang, S.; Braidy, N.; Maleki, S.; Lal, S.; Richardson, D.R.; Huang, M.L. Mechanisms of impaired mitochondrial homeostasis and $\mathrm{NAD}^{+}$metabolism in a model of mitochondrial heart disease exhibiting redox active iron accumulation. Redox Biol. 2021, 46, 102038. [CrossRef]

182. Abdellatif, M.; Trummer-Herbst, V.; Koser, F.; Durand, S.; Adao, R.; Vasques-Novoa, F.; Freundt, J.K.; Voglhuber, J.; Pricolo, M.R.; Kasa, M.; et al. Nicotinamide for the treatment of heart failure with preserved ejection fraction. Sci. Transl. Med. $2021,13$. [CrossRef]

183. Tong, D.; Schiattarella, G.G.; Jiang, N.; Altamirano, F.; Szweda, P.A.; Elnwasany, A.; Lee, D.I.; Yoo, H.; Kass, D.A.; Szweda, L.I.; et al. NAD ${ }^{+}$Repletion Reverses Heart Failure with Preserved Ejection Fraction. Circ. Res. 2021, 128, $1629-1641$. [CrossRef] [PubMed]

184. Horton, J.L.; Martin, O.J.; Lai, L.; Riley, N.M.; Richards, A.L.; Vega, R.B.; Leone, T.C.; Pagliarini, D.J.; Muoio, D.M.; Bedi, K.C., Jr.; et al. Mitochondrial protein hyperacetylation in the failing heart. JCI Insight 2016, 2. [CrossRef] [PubMed]

185. Hsu, C.P.; Yamamoto, T.; Oka, S.; Sadoshima, J. The function of nicotinamide phosphoribosyltransferase in the heart. DNA Repair 2014, 23, 64-68. [CrossRef]

186. Tannous, C.; Booz, G.W.; Altara, R.; Muhieddine, D.H.; Mericskay, M.; Refaat, M.M.; Zouein, F.A. Nicotinamide adenine dinucleotide: Biosynthesis, consumption and therapeutic role in cardiac diseases. Acta Physiol. 2021, 231, e13551. [CrossRef] [PubMed]

187. Tannous, C.; Deloux, R.; Karoui, A.; Mougenot, N.; Burkin, D.; Blanc, J.; Coletti, D.; Lavery, G.; Li, Z.; Mericskay, M. NMRK2 Gene Is Upregulated in Dilated Cardiomyopathy and Required for Cardiac Function and NAD Levels during Aging. Int. J. Mol. Sci. 2021, 22, 3534. [CrossRef]

188. Walker, M.A.; Tian, R. Raising NAD in Heart Failure: Time to Translate? Circulation 2018, 137, 2274-2277. [CrossRef] [PubMed]

189. Akar, F.G.; Young, L.H. NAD Repletion Therapy: A Silver Bullet for HFpEF? Circ. Res. 2021, 128, 1642-1645. [CrossRef]

190. Zhou, B.; Wang, D.D.; Qiu, Y.; Airhart, S.; Liu, Y.; Stempien-Otero, A.; O’Brien, K.D.; Tian, R. Boosting NAD level suppresses inflammatory activation of PBMCs in heart failure. J. Clin. Investig. 2020, 130, 6054-6063. [CrossRef]

191. Ostman-Smith, I.; Brown, G.; Johnson, A.; Land, J.M. Dilated cardiomyopathy due to type II X-linked 3-methylglutaconic aciduria: Successful treatment with pantothenic acid. Br. Heart J. 1994, 72, 349-353. [CrossRef] [PubMed]

192. Kose, A.; Parlakpinar, H.; Ozhan, O.; Ermis, N.; Yildiz, A.; Vardi, N.; Cigremis, Y. Therapeutic effects of dexpanthenol on the cardiovascular and respiratory systems following cecal ligation and puncture-induced sepsis in rats. Biotech. Histochem. 2020, 95, 428-437. [CrossRef] 
193. Kalkan, F.; Parlakpinar, H.; Disli, O.M.; Tanriverdi, L.H.; Ozhan, O.; Polat, A.; Cetin, A.; Vardi, N.; Otlu, Y.O.; Acet, A. Protective and therapeutic effects of dexpanthenol on isoproterenol-induced cardiac damage in rats. J. Cell. Biochem. 2018, 119, 7479-7489. [CrossRef]

194. Demirci, B.; Demir, O.; Dost, T.; Birincioglu, M. Protective effect of vitamin B5 (dexpanthenol) on cardiovascular damage induced by streptozocin in rats. Bratisl Lek Listy 2014, 115, 190-196. [CrossRef]

195. Velazquez-Arellano, A.; Hernandez-Esquivel Mde, L.; Sanchez, R.M.; Ortega-Cuellar, D.; Rodriguez-Fuentes, N.; Cano, S.; Leon-Del-Rio, A.; Carvajal, K. Functional and metabolic implications of biotin deficiency for the rat heart. Mol. Genet. Metab. 2008, 95, 213-219. [CrossRef]

196. Lippi, G.; Plebani, M. Hyperhomocysteinemia in health and disease: Where we are now, and where do we go from here ? Clin. Chem. Lab. Med. 2012, 50, 2075-2080. [CrossRef]

197. Marti-Carvajal, A.J.; Sola, I.; Lathyris, D.; Karakitsiou, D.E.; Simancas-Racines, D. Homocysteine-lowering interventions for preventing cardiovascular events. Cochrane Database Syst. Rev. 2009, 4, CD006612. [CrossRef]

198. Qureshi, S.S.; Gupta, J.K.; Goyal, A.; Narayan Yadav, H. A novel approach in the management of hyperhomocysteinemia. Med. Hypotheses 2019, 129, 109245. [CrossRef]

199. Strauss, E.; Supinski, W.; Radziemski, A.; Oszkinis, G.; Pawlak, A.L.; Gluszek, J. Is hyperhomocysteinemia a causal factor for heart failure? The impact of the functional variants of MTHFR and PON1 on ischemic and non-ischemic etiology. Int. J. Cardiol. 2017, 228, 37-44. [CrossRef]

200. Vizzardi, E.; Bonadei, I.; Zanini, G.; Frattini, S.; Fiorina, C.; Raddino, R.; Dei Cas, L. Homocysteine and heart failure: An overview. Recent Pat. Cardiovasc. Drug Discov. 2009, 4, 15-21. [CrossRef]

201. Herrmann, M.; Muller, S.; Kindermann, I.; Gunther, L.; Konig, J.; Bohm, M.; Herrmann, W. Plasma B vitamins and their relation to the severity of chronic heart failure. Am. J. Clin. Nutr. 2007, 85, 117-123. [CrossRef]

202. Agoston-Coldea, L.; Mocan, T.; Gatfosse, M.; Lupu, S.; Dumitrascu, D.L. Plasma homocysteine and the severity of heart failure in patients with previous myocardial infarction. Cardiol. J. 2011, 18, 55-62. [PubMed]

203. Polytarchou, K.; Dimitroglou, Y.; Varvarousis, D.; Christodoulis, N.; Psachoulia, C.; Pantziou, C.; Mourouzis, I.; Pantos, C.; Manolis, A.S. Methylmalonic acid and vitamin B12 in patients with heart failure. Hellenic J. Cardiol. 2020, 61, 330-337. [CrossRef] [PubMed]

204. Herzlich, B.C.; Lichstein, E.; Schulhoff, N.; Weinstock, M.; Pagala, M.; Ravindran, K.; Namba, T.; Nieto, F.J.; Stabler, S.P.; Allen, R.H.; et al. Relationship among homocyst(e)ine, vitamin B-12 and cardiac disease in the elderly: Association between vitamin B-12 deficiency and decreased left ventricular ejection fraction. J. Nutr. 1996, 126, 1249S-1253S. [CrossRef] [PubMed]

205. Allard, M.L.; Jeejeebhoy, K.N.; Sole, M.J. The management of conditioned nutritional requirements in heart failure. Heart Fail. Rev. 2006, 11, 75-82. [CrossRef]

206. Van der Wal, H.H.; Comin-Colet, J.; Klip, I.T.; Enjuanes, C.; Grote Beverborg, N.; Voors, A.A.; Banasiak, W.; van Veldhuisen, D.J.; Bruguera, J.; Ponikowski, P.; et al. Vitamin B12 and folate deficiency in chronic heart failure. Heart 2015, 101, 302-310. [CrossRef]

207. Aksoy, N.; Aksoy, M.; Cakmak, M.; Gergerlioglu, H.S.; Davutoglu, V.; Soydinc, S.; Meram, I. Increased homocysteine in heart failure: A result of renal impairment? Clin. Chem. Lab. Med. 2006, 44, 1324-1329. [CrossRef]

208. Ipcioglu, O.M.; Ozcan, O.; Gultepe, M.; Ates, A.; Basoglu, C.; Cakir, E. Reduced urinary excretion of homocysteine could be the reason of elevated plasma homocysteine in patients with psychiatric illnesses. Clin. Biochem. 2008, 41, 831-835. [CrossRef]

209. Stuhlinger, M.C.; Tsao, P.S.; Her, J.H.; Kimoto, M.; Balint, R.F.; Cooke, J.P. Homocysteine impairs the nitric oxide synthase pathway: Role of asymmetric dimethylarginine. Circulation 2001, 104, 2569-2575. [CrossRef]

210. Tyagi, N.; Ovechkin, A.V.; Lominadze, D.; Moshal, K.S.; Tyagi, S.C. Mitochondrial mechanism of microvascular endothelial cells apoptosis in hyperhomocysteinemia. J. Cell. Biochem. 2006, 98, 1150-1162. [CrossRef]

211. Munjal, C.; Tyagi, N.; Lominadze, D.; Tyagi, S.C. Matrix metalloproteinase-9 in homocysteine-induced intestinal microvascular endothelial paracellular and transcellular permeability. J. Cell. Biochem. 2012, 113, 1159-1169. [CrossRef]

212. Majors, A.; Ehrhart, L.A.; Pezacka, E.H. Homocysteine as a risk factor for vascular disease. Enhanced collagen production and accumulation by smooth muscle cells. Arter. Thromb. Vasc. Biol. 1997, 17, 2074-2081. [CrossRef]

213. Zhao, J.; Chen, H.; Liu, N.; Chen, J.; Gu, Y.; Chen, J.; Yang, K. Role of Hyperhomocysteinemia and Hyperuricemia in Pathogenesis of Atherosclerosis. J. Stroke Cerebrovasc. Dis. 2017, 26, 2695-2699. [CrossRef]

214. Joseph, J.; Washington, A.; Joseph, L.; Koehler, L.; Fink, L.M.; Hauer-Jensen, M.; Kennedy, R.H. Hyperhomocysteinemia leads to adverse cardiac remodeling in hypertensive rats. Am. J. Physiol. Heart Circ. Physiol. 2002, 283, H2567-H2574. [CrossRef]

215. Joseph, J.; Joseph, L.; Shekhawat, N.S.; Devi, S.; Wang, J.; Melchert, R.B.; Hauer-Jensen, M.; Kennedy, R.H. Hyperhomocysteinemia leads to pathological ventricular hypertrophy in normotensive rats. Am. J. Physiol. Heart Circ. Physiol. 2003, 285, H679-H686. [CrossRef]

216. Kennedy, R.H.; Owings, R.; Shekhawat, N.; Joseph, J. Acute negative inotropic effects of homocysteine are mediated via the endothelium. Am. J. Physiol. Heart Circ. Physiol. 2004, 287, H812-H817. [CrossRef]

217. Kennedy, R.H.; Owings, R.; Joseph, J.; Melchert, R.B.; Hauer-Jensen, M.; Boerma, M. Acute dilatory and negative inotropic effects of homocysteine are inhibited by an adenosine blocker. Clin. Exp. Pharmacol. Physiol. 2006, 33, 340-344. [CrossRef]

218. Clarke, R.; Halsey, J.; Lewington, S.; Lonn, E.; Armitage, J.; Manson, J.E.; Bonaa, K.H.; Spence, J.D.; Nygard, O.; Jamison, R.; et al. Effects of lowering homocysteine levels with B vitamins on cardiovascular disease, cancer, and cause-specific mortality: Metaanalysis of 8 randomized trials involving 37485 individuals. Arch. Intern. Med. 2010, 170, 1622-1631. [CrossRef] 
219. Ebbing, M.; Bonaa, K.H.; Arnesen, E.; Ueland, P.M.; Nordrehaug, J.E.; Rasmussen, K.; Njolstad, I.; Nilsen, D.W.; Refsum, H.; Tverdal, A.; et al. Combined analyses and extended follow-up of two randomized controlled homocysteine-lowering B-vitamin trials. J. Intern. Med. 2010, 268, 367-382. [CrossRef]

220. Towfighi, A.; Arshi, B.; Markovic, D.; Ovbiagele, B. Homocysteine-lowering therapy and risk of recurrent stroke, myocardial infarction and death: The impact of age in the VISP trial. Cerebrovasc. Dis. 2014, 37, 263-267. [CrossRef]

221. Li, Y.; Huang, T.; Zheng, Y.; Muka, T.; Troup, J.; Hu, F.B. Folic Acid Supplementation and the Risk of Cardiovascular Diseases: A Meta-Analysis of Randomized Controlled Trials. J. Am. Heart Assoc. 2016, 5. [CrossRef]

222. Wang, Y.; Jin, Y.; Wang, Y.; Li, L.; Liao, Y.; Zhang, Y.; Yu, D. The effect of folic acid in patients with cardiovascular disease: A systematic review and meta-analysis. Medicine 2019, 98, e17095. [CrossRef] [PubMed]

223. Qipshidze, N.; Tyagi, N.; Sen, U.; Givvimani, S.; Metreveli, N.; Lominadze, D.; Tyagi, S.C. Folic acid mitigated cardiac dysfunction by normalizing the levels of tissue inhibitor of metalloproteinase and homocysteine-metabolizing enzymes postmyocardial infarction in mice. Am. J. Physiol. Heart Circ. Physiol. 2010, 299, H1484-H1493. [CrossRef] [PubMed]

224. Octavia, Y.; Kararigas, G.; de Boer, M.; Chrifi, I.; Kietadisorn, R.; Swinnen, M.; Duimel, H.; Verheyen, F.K.; Brandt, M.M.; Fliegner, D.; et al. Folic acid reduces doxorubicin-induced cardiomyopathy by modulating endothelial nitric oxide synthase. $J$. Cell. Mol. Med. 2017, 21, 3277-3287. [CrossRef] [PubMed]

225. Ahmad, S.; Panda, B.P.; Kohli, K.; Fahim, M.; Dubey, K. Folic acid ameliorates celecoxib cardiotoxicity in a doxorubicin heart failure rat model. Pharm. Biol. 2017, 55, 1295-1303. [CrossRef] [PubMed]

226. Li, W.; Tang, R.; Ouyang, S.; Ma, F.; Liu, Z.; Wu, J. Folic acid prevents cardiac dysfunction and reduces myocardial fibrosis in a mouse model of high-fat diet-induced obesity. Nutr. Metab. 2017, 14, 68. [CrossRef] [PubMed]

227. Ye, S.; Zhou, X.; Chen, P.; Lin, J.F. Folic acid attenuates remodeling and dysfunction in the aging heart through the ER stress pathway. Life Sci. 2021, 264, 118718. [CrossRef]

228. Lamberts, R.R.; Caldenhoven, E.; Lansink, M.; Witte, G.; Vaessen, R.J.; St Cyr, J.A.; Stienen, G.J. Preservation of diastolic function in monocrotaline-induced right ventricular hypertrophy in rats. Am. J. Physiol. Heart Circ. Physiol. 2007, 293, H1869-H1876. [CrossRef]

229. Jakovljevic Uzelac, J.; Djukic, T.; Radic, T.; Mutavdzin, S.; Stankovic, S.; Rakocevic, J.K.; Labudovic Borovic, M.; Milic, N.; Simic, T.; Savic-Radojevic, A.; et al. Folic acid affects cardiometabolic, oxidative stress, and immunohistochemical parameters in monocrotaline-induced rat heart failure. Can. J. Physiol. Pharmacol. 2020, 98, 708-716. [CrossRef]

230. Ruiz, M.; Courilleau, D.; Jullian, J.C.; Fortin, D.; Ventura-Clapier, R.; Blondeau, J.P.; Garnier, A. A cardiac-specific robotized cellular assay identified families of human ligands as inducers of PGC-1alpha expression and mitochondrial biogenesis. PLoS ONE 2012, 7, e46753. [CrossRef]

231. Hagar, H.H. Folic acid and vitamin $\mathrm{B}(12)$ supplementation attenuates isoprenaline-induced myocardial infarction in experimental hyperhomocysteinemic rats. Pharmacol. Res. 2002, 46, 213-219. [CrossRef]

232. Piquereau, J.; Moulin, M.; Zurlo, G.; Mateo, P.; Gressette, M.; Paul, J.L.; Lemaire, C.; Ventura-Clapier, R.; Veksler, V.; Garnier, A. Cobalamin and folate protect mitochondrial and contractile functions in a murine model of cardiac pressure overload. J. Mol. Cell. Cardiol. 2016, 102, 33-44. [CrossRef]

233. Miner, S.E.; Cole, D.E.; Evrovski, J.; Forrest, Q.; Hutchison, S.; Holmes, K.; Ross, H.J. Pyridoxine improves endothelial function in cardiac transplant recipients. J. Heart Lung Transplant. 2001, 20, 964-969. [CrossRef]

234. Balmain, B.N.; Jay, O.; Morris, N.R.; Stewart, G.M.; Shiino, K.; McFarland, A.J.; Jayasinghe, R.; Chan, J.; Sabapathy, S. Folic acid supplementation improves vascular endothelial function, yet not skin blood flow during exercise in the heat, in patients with heart failure. Am. J. Physiol. Regul. Integr. Comp. Physiol. 2018, 315, R810-R819. [CrossRef]

235. Pillai, V.B.; Sundaresan, N.R.; Kim, G.; Gupta, M.; Rajamohan, S.B.; Pillai, J.B.; Samant, S.; Ravindra, P.V.; Isbatan, A.; Gupta, M.P. Exogenous NAD blocks cardiac hypertrophic response via activation of the SIRT3-LKB1-AMP-activated kinase pathway. J. Biol. Chem. 2010, 285, 3133-3144. [CrossRef] 